\title{
Resilience in Retrospective: The Trajectory of Agro-Pastoral Systems in the Centro Region of Portugal
}

\author{
Isabel Dinis ${ }^{1,2, *(D)}$ and Orlando Simões ${ }^{1,2}$ \\ 1 Instituto Politécnico de Coimbra, Escola Superior Agrária de Coimbra, 3045-601 Coimbra, Portugal; \\ orlando@esac.pt \\ 2 Research Centre for Natural Resources, Environment and Society (CERNAS), \\ Escola Superior Agrária de Coimbra, 3045-601 Coimbra, Portugal \\ * Correspondence: idinis@esac.pt; Tel.: +351-239-802-280
}

Citation: Dinis, I.; Simões, O. Resilience in Retrospective: The Trajectory of Agro-Pastoral Systems in the Centro Region of Portugal. Sustainability 2021, 13, 5089. https:// doi.org/10.3390/su13095089

Academic Editor: Črtomir Rozman

Received: 8 April 2021

Accepted: 30 April 2021

Published: 1 May 2021

Publisher's Note: MDPI stays neutral with regard to jurisdictional claims in published maps and institutional affiliations.

Copyright: (c) 2021 by the authors. Licensee MDPI, Basel, Switzerland. This article is an open access article distributed under the terms and conditions of the Creative Commons Attribution (CC BY) license (https:// creativecommons.org/licenses/by/ $4.0 /)$.

\begin{abstract}
Agro-pastoral systems in southern European regions have been subjected to various disturbances in the past few decades. Still, a certain amount of resilience allowed to withstand its sharp decline. The Serra da Estrela cheese production, the most representative agro-pastoral system of the Portuguese Centro Region, is a demonstrative case study. The main objective of this research is to understand the trajectory of this system up to present, its adaptation to internal and external changes and evolution trends. We used the concepts of resilience and socio-ecological system as framework in a qualitative study. Participatory methods were applied using the perspectives of local actors, in order to identify and analyze the key factors. The main drivers are socio-demographic (ageing, depopulation, social perception of the profession), economic (free market, industrialization), political (lack of adequate of national and European policies) and environmental (climate change, forest fires). Our results are in line with other European cases. To cope with these trends, the system is irreversibly transforming, moving into a new trajectory characterized by different systemic architecture. In face of the ongoing changes, the interactions between the social and the ecological subsystems are blurring, whereas local communities and traditions are being excluded.
\end{abstract}

Keywords: socio-ecological systems; PDO; Serra da Estrela

\section{Introduction}

Pastoral systems can be defined as adaptive networks of biophysical and social flows generated and maintained by the movement of shepherds and livestock, taking advantage of the uneven distribution of natural and economic resources [1,2]. Pastoral systems are socio-ecological systems (SES) in the sense that they are a product of complex interactions between ecosystems and society, which shape landscape, resources, biodiversity and animal breeds, as well as local tradition, in different ways. However, in the last decades, in most regions of southern Europe, Portugal being no exception, agro-pastoral systems have been experiencing a sharp decline [3-8], both in the number of farms and animals. In Italy, for instance, the reorganization of the mountain rural areas has been accompanied by considerable reductions in the size of the herds and flocks [3]. The decrease in the number of animals and the increasing uncertainty regarding the reproducibility of these farming systems is also notorious in the north eastern Spain [6] and other regions of Spain, Greece and Italy [5].

In the case of the mountain areas of the Portuguese Centro Region, milk sheep for artisanal cheese production is the most traditional pastoral system, nowadays strongly threatened by abandonment. Between 1999 and 2019, the number of milk sheep and milk sheep farms decreased, respectively, by $53 \%$ and $76 \%$ in the region [9]. The drastic reduction in the number of farms probably resulted from their low capacity to absorb disturbance and reorganize while undergoing change so as to still retain essentially the same function, 
structure, identity and feedbacks, to use the terminology proposed by Walker et al. [10] in their definition of resilience.

Different categories of disturbances, ranging from global to local level, are affecting agro-pastoral systems. Some examples are climate change [11], the increasing industrialization and urbanization [12] or the profound changes in the Common Agricultural Policy (CAP) [6]. The decline of pastoral systems around the world can be understood as a result of the combination of different factors including: (i) Social perception of pastoralism as an unattractive profession; (ii) Unfocused governance; (iii) Economic systems that create markets where pastoral systems cannot compete and (iv) Depopulation and ageing [2] Generally speaking, to cope with these permanent shocks, rural areas and farms that were able to maintain some vitality had to develop a certain amount of resilience, i.e., the ability to respond to disturbances, resisting damage and recovering quickly.

Resilience applied to the rural and farming context has received some attention from scientific research all over the world. Regarding rural communities, [13] analyzes the role of economic factors in rural sustainability in Australia, while [14] applies the resilience thinking to study the effect of rural development policies on the resilience of Danish rural areas. Another example can be found in [15], who investigates the role of a small cereal cooperative in the Swiss Alps, in supporting farming and how resilience within the socio-ecological system is enhanced as the cooperative exploits evolving forms of collaboration, market niches, and private and public governance relationships to respond to agro-ecological, economic and political risks. Other authors [16,17] explored the role of agro ecological policy measures in strengthening the resilience of farmers and rural communities, finding that strategies such as crop diversification, genetic diversity, animal integration, soil organic management and water conservation can reduce vulnerabilities to climate variability.

For the Portuguese case, however, there are no studies explicitly targeting the resilience of rural communities. The main objective of this research is to fill this gap by understanding the trajectory of agro-pastoral systems in the Portuguese Centro Region, from the perspective of local actors, using resilience thinking and the concept of socioecological system as a framework and the most representative agro-pastoral system in the Portuguese Centro Region-Serra da Estrela cheese production system-as a qualitative case study. We try to identify and analyze the key drivers that have influenced the system in the past few decades, to understand the ways in which the system adapted to external and internal changes and assess its current state. To do so we use a participatory approach, relying on the memory and perspectives of local actors. Therefore, although the integration of ecosystems and human society is present in the analysis, our focus is mainly on the faster-changing components that impact people more directly.

The knowledge of the factors affecting the resilience of the Serra da Estrela rural community can be used by farmers and local development actors towards the adoption of internal strategies conducive to strengthening their own resilience. At a broader level, this study may contribute to the design of more effective national and European agricultural policies that support agro-pastoral systems as a lever for rural territories dynamic and for the so-called agro ecological transition. Besides this, as pointed out by the United Nations Convention to Combat Desertification, agro-pastoralism is a climate change mitigation option [18]. Although based on a local case study, the present research tackles a global issue and may contribute to systematic learning from experience and, at the same time, encourage cross-site comparisons and contribute to theory development.

\section{Literature Review}

Resilience is a concept originally used in Physics to describe the stability of different kinds of materials to external shocks. The concept was further developed by [19] to explain the extent to which an ecosystem is able to return to a stable state after a shock and later applied by many authors in a wide range of fields, such as firm management $[20,21]$, transportations systems [22,23], urban planning [24,25] and migration studies [26]. 
When applied to rural areas, resilience refers to their ability to adapt to changes in the external environment, dealing with the inherent ecological, economic and social vulnerability in such a way that a satisfactory standard of living is maintained in these areas [27]. Becoming more resilient, a rural area may face changes without ending up in a negative cycle of depopulation and economic and social decline. As stated by [28], referring to rural areas, a resilient system possesses a greater capacity to prevent undesirable results in the face of external disturbances, while continuing to provide the goods and services that support quality of life. The concept of rural resilience refers to the level up to which a specific rural area is able to tolerate change before reorganizing around a new set of structures and processes [27]. According to [14], the resilience issue is particularly relevant in rural areas because farmers' income is highly unpredictable as a result of agricultural and food markets specificities.

Central to resilience thinking is the concept of socio-ecological system [29,30]. Although a thorough definition of SES still missing [31], it involves recognizing that, in isolation, the study of the economic, social and ecological dimensions can only provide a partial understanding of the resilience mechanisms in a given context. Therefore, reciprocal socio-ecological relationships, in which rural communities influence ecosystems and vice versa, must be considered $[32,33]$. Humans adjust to the influences of the environment and try to modify it in the pursuit of certain social goals. As underlined by [34], resilience can be analyzed in three dimensions: (1) the amount of change the system can undergo and still retain the same functions and structure; (2) the degree to which the system is capable of self-organization; and (3) the ability to build and increase the capacity for learning and adaptation. These reciprocal cycles of mutual influence between environment and people results in a pattern of continually evolving and mutually adaptive transactions, known as the adaptive cycle, well described in the literature [30,32,35-37].

According to the theory of the adaptive cycle, SES do not tend towards equilibrium. Rather, they go through different types of changes, from growth and accumulation to novelty and renewal, according to four phases: rapid growth and exploitation (r), conservation $(\mathrm{K})$, collapse or release $(\Omega)$, and renewal or reorganization $(\alpha)$. As a consequence of the periodic, but transient, phases of creative destruction ( $\Omega$ stage) and renewal ( $\alpha$ stage), each level of a system's structure and processes can be reorganized. This rearranging allows for new system configurations and new opportunities that can be seized by external and novel entrants [36].

This dynamic can generate three different outcomes: persistence, adaptability and transformability [32]. Persistence is the ability to remain within a stability domain, continually changing and adapting yet remaining within critical thresholds. Adaptability is the capacity to adjust and thereby allow for development within the current stability domain, along the current trajectory. Transformability is the capacity to create new stability domains for development and cross thresholds into a new trajectory. In other words, if a shock can be buffered the system may return to its previous state; otherwise, it will transform [38]. Transformation or collapse ( $\Omega$ phase) is a shift from the current system to a substantively new and different one, that has different structural and functional properties and supplies different bundles of the ecosystem services that benefit people [30,39]. For a transformation or collapse to occur, four conditions must be met: the identity of the socialecological system must be lost; the loss of identity should happen fast; substantial losses of social-ecological capital occur and the consequences of collapse must be lasting [40].

Until recently, the literature on socio-ecological systems mainly used resilience as a metaphor or theoretical construct [41] with limited application in the real-world [42]. The adaptive cycle remained essentially a heuristic device dissociated from analytical tools capable of quantitatively assessing resilience, particularly in the social sub-subsystem [43]. Nevertheless, in the last decade, several empirical case studies, often relying in qualitative research methods (e.g., [12,44-47]), were developed, some of them specifically addressing the resilience of SES in mountain regions [1-3,6,48,49]. Furthermore, establishing a link between environmental changes that affect the ability of the ecological sub-system to provide 
ecosystem services and the effect that changes in the ecosystem services provision have on the welfare of the social sub-system, is a complex task, since the spatial and temporal scales of the changes in both sub-systems may be very different [50]. This may explain why studies on socio-ecological systems resilience, with mountain studies being no exception, tend to focus either on the ecological $[1,48,49]$ or the social part $[15,51,52]$ of the system. As stated by [35], the resilience of certain parts of the system, within certain time periods, may well differ from the resilience of the entire system over more extended temporal periods. In general, the ecological sub-system components have slowly changing variables, whereas socio-economic components mainly have fast changing characteristics [29].

Generally speaking, the human side of SES modeling has received relatively little attention in comparison to the ecological side [53]. If the impact of shocks on the social sub-system is poorly understood and misestimated, however, public policies risk to fail people, places and systems in different contexts, as stated by [54], referring to the effect of strong neoliberal policies on local communities.

Market liberalization is often pointed as disempowering for local communities since, via the price mechanism and the interconnectedness of markets and sectors, it favors the higher scales within the system and reduces businesses integration in the local economy and social community. Furthermore, the exposure to strongly competitive market conditions encourage the transformation of the social sub-system by increasing mechanization, industrialization and a less sustainable use of resources $[55,56]$. Paradoxically, market regulations, such as quality standards and animal welfare demands, may also have a negative impact on farmer's resilience. These continuously demanding regulations, as well as the uncertainty regarding the evolution of the CAP, affects farmers and other food producers' ability to plan ahead and to manage their farms so as to ensure farm continuity [56].

Community's empowerment, i.e., the capacity to act in making its own choices relies on leadership, social networking and trust [57]. It has been raised by several authors $[55,58,59]$ that partnerships that encompass local, regional and national levels of government are vital for establishing the necessary links between different scales in a SES, particularly with regard to knowledge generation and sharing. Many of the recent studies on SES resilience (e.g., [11,32,35,58,60]) acknowledge the need for organizations and institutions to learn from past events (learning-by doing) in order to adapt to change. This is known as adaptive management [59]. It means that not only the knowledge produced by farmers and grassroots-based organizations should be taken into account by policy makers, but also that local communities need to have access to the knowledge produced in other parts of the system. As stated by [58], "all stakeholders, including farmers, need to be recognized as equal co-authors of knowledge generation, and all kinds of knowledge, both formal and informal, need be brought together in innovation processes".

This need to bring together multi-actor knowledge, enabling new more integrated visions and solutions, guided our methodological choices, which are presented in the following section.

\section{Methodological Framework}

\subsection{Resilience in Socio-Ecological Systems}

Walker and Salt [28] identify nine attributes that characterize a resilient world, five of which have special relevance in rural resilience and work as a reference throughout the present analysis: diversity, modularity, social capital, innovation and overlap in governance. Diversity increases the options for coping with shocks and stresses and provides more opportunities in the renewal cycle, making the system less vulnerable in the face of hazards. Regarding farm systems, diversity can enhance the resilience because it reduces the dependence on a single activity as well as the variability of income. Diversity is needed at the environmental, economic and social levels, in the form of biodiversity, diversity of income, sources of funding, insurance, savings and diversity of relationship types and information sources $[28,56,59,61]$. 
Modularity means that a system is composed of different functional parts that can evolve independently. Thus, disturbances are more slowly transmitted through the entire system [14]. For example, the existence of different types of farm structures may increase the resilience of a rural community.

As for social capital, Schouten et al. [14], quoting several authors, note that strongly connected rural communities are more resilient because they have lower transaction and monitoring costs. Besides this, knowledge can be more easily exchanged and people can become less risk-averse due to the safety net provided by the community. As stated by [38], the networks and the information flows enable farmers to "read" their context, detect threats, assess opportunities, proactively discuss emerging options and gauge the wider ramification of trends and sudden shocks. A lack of trust within the social network leads to inefficient information flows and deteriorates the social structure and thereby the system's resilience [29,62].

The ability to adopt innovations that allow to adjust usual practices, maintaining self-organization while evolving is also a feature of resilient systems. Although stability is a desirable feature in resilience thinking, it does not mean immutability since SES are constantly changing. The system's flexibility to adapt to external shocks and its capacity for learning and renewal in a dynamic setting is crucial for rural resilience. Within the SES approach, farms are interpreted as learning systems whose survival and growth strongly depends on the successful generation and integration of new knowledge $[6,27,55,56,63]$. It is argued that combining traditional, local knowledge with more globalized, scientific knowledge can develop collaboration and communication and helps increase the system capacity to learn. Farmers are not passive recipients of information and knowledge. They are active in identifying problems and addressing them [38,61].

Regarding governance, it is expected that a greater diversity in governmental structures and levels of implementation will increase the system flexibility and responsiveness, ensuring greater resilience [14,28].

\subsection{Research Methods}

Building on the adaptive-cycle model, the Resilience Alliance, an interdisciplinary network of scientists and practitioners focused on SES perspective, developed the Resilience Assessment Framework (RAF). In the present research we used this framework as a guide for constructing the conceptual model of the agro-pastoral system in Serra da Estrela, following RAF five main stages: (1) describing the system; (2) understanding the system dynamics; (3) probing system interactions; (4) evaluating governance; and (5) acting on the assessment [30].

The first step to describe the system (stage 1) is to define its socio-ecological boundaries, both at spatial and temporal levels, able to include the critical system components. The following step consists of identifying the main issues of concern for the assessment and recognizing the key components of the SES that are relevant to the main issue in order to understand the way in which the system works, the different scales of interest, the actors and the system's functions and properties (resilience of what). The final step is to understand the disturbance regime i.e., the pattern of disturbance events over time (resilience to what). The understanding of the system dynamics (stage 2) involves describing its current state as well as its historical and potential future states. A state is defined by its key components and how they interact, function and respond to both internal and external changes. It also involves describing the thresholds and system drivers linked with these state changes. System interaction (stage 3) analyzes the influences on the system by larger-scale systems in which it is embedded, as well as with the smaller-scale systems of which it is comprised. Evaluating governance (stage 4) involves the identification of actors of multiple sectors and scales and the understanding of how individuals, organizations, rules and traditions are related to people decisions and power sharing. In the final stage of RAF, which is not in the aim of the present retrospective study, all the findings along the 
assessment are synthesized, stewardship strategies to enhance socio-ecological resilience are proposed and the capacity of the system to respond to change is discussed.

In order to identify the key components of the SES, to understand the pattern of disturbance events over time and the main strategies and responses adopted by local actors, a participatory research was implemented. As stated by several authors $[1,11,35,56,64]$ participatory methods are recommended for this type of modeling approach because it is important to incorporate the perspectives and opinions of a wide variety of actors and to combine different types of knowledge.

Data collection started with the authors' participation in the Public Hearing "Defending the production and the producers of Serra da Estrela Cheese", organized by a political party in July 2018, in which several shepherds, cheese producers and local population in general discussed the trajectory of the Serra da Estrela agro-pastoral system. Although the authors had some past research experience in the subject, the Hearing allowed a better understanding of the current main issues affecting the system. Later, between October 2018 and February 2019, seeking a more in-depth understanding of the system dynamics and interactions, 16 face-to-face semi-structured interviews were carried out, with different categories of stakeholders: 3 shepherds; 2 shepherds/Protected Designation of Origin (PDO) cheese producers; 4 shepherds/artisanal cheese (not PDO) producers; 1 PDO cheese producer; 1 manager of a PDO artisanal cheese factory; 3 technicians from farmers organizations; 1 technician from the Ministry of Agriculture; and 1 former technician from Serra da Estrela Natural Park.

The identification and selection of participants in each stakeholder category was initially done using local and regional key informants. These included farmer's organizations, the Ministry of Agriculture and researchers involved in local projects. The initial group of respondents then guided us to other contacts, in a process known as snowball sampling. The choice of the number of interviews followed the principle of saturation, in the sense that we stopped the survey at the point at which additional data do not led to any new emergent themes [65]. Although not free of inconsistencies and contradictions in its use [66], saturation has wide acceptance as a methodological tool in qualitative research.

An interview schedule for predetermined topics was used as a guide but the interviews were essentially a co-construction between the interviewer and the interviewee. All subjects gave their informed consent for inclusion before they participated in the study. The interviews lasted between fifty minutes and two hours and were recorded and saved by an audio device.

The interviews, as well as the Hearing audio records, were later transcribed and imported into NVivo 11 Pro software for content analysis. The participants' statements were coded in a set of four nodes corresponding to the first four RAF main stages. All the participants were coded as cases regarding their typology ( $\mathrm{SH}$-shepherds; $\mathrm{PDO}-$ PDO cheese producers; $\mathrm{CH}$-artisanal (not PDO) cheese producers; $\mathrm{M}$-managers of PDO cheese factories; $\mathrm{T}$-technicians; $\mathrm{C}$-local citizen) and first and last name initials (except for the participants in the Hearing that were all coded as $\mathrm{H}$ ). For example, $\mathrm{SH} / \mathrm{CH}-\mathrm{AA}$ stands for a shepherd that produces artisanal (not PDO) cheese whose first and last names begin by an A. A comprehensive overview and detailed description of the content analysis method is discussed in [67].

\subsection{Study Area}

Following the Resilience Assessment Framework [30], the first step to describe a system is to define the spatial and temporal limits that comprise the focal system. Therefore, before starting the identification of the main issues regarding the Serra da Estrela agropastoral system, several potential delimitations, with more or less administrative, natural or socio-economic backgrounds (NUT III Serra da Estrela, Serra da Estrela National Park area; Serra da Estrela DOP area) were taken into consideration. Since the geographical area of Serra da Estrela PDO (includes cheese, lambs and curd) was a participatory construction designed to include all the most relevant components of the system, it was decided to choose it as 
the SES spatial boundaries. The PDO comprises a geographical area of $3143.16 \mathrm{~km}^{2}$, which includes the municipalities on the mountain and contiguous western plains (Figure 1).
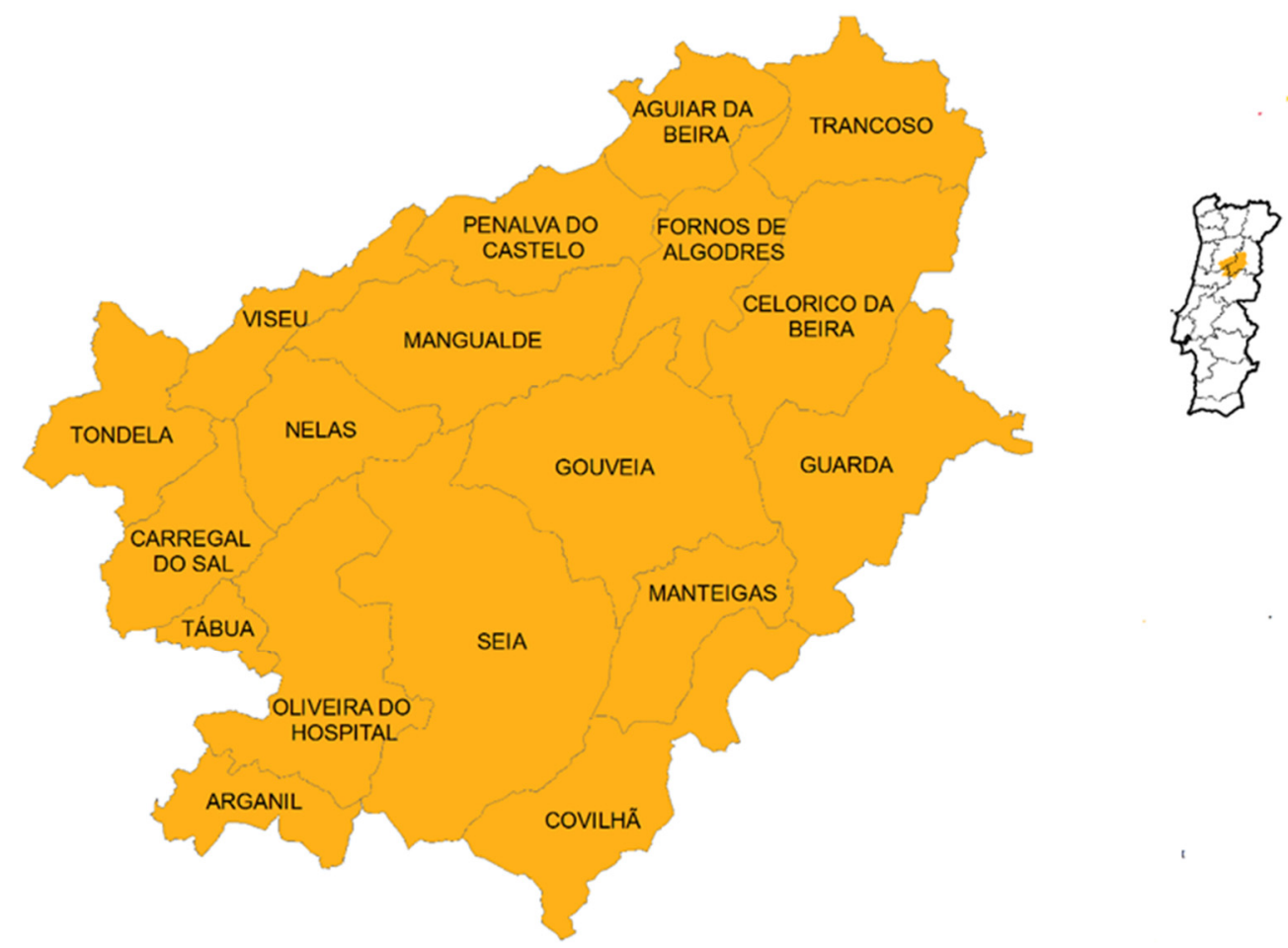

Figure 1. Serra da Estrela PDO Geographical Area (Source: DGADR [68]).

From a socio-economic perspective, around 361,500 people lived in the geographical area of Serra da Estrela PDO in 2019, 25\% of which were aged 65 and over [69]. The area remains largely rural, with $66 \%$ of the population living in places with less than 2000 inhabitants [70]. Regarding employment, the most relevant sectors are manufacturing, commerce and construction. Agriculture represents only 5.7\% of the employment [71]. However, given the family nature of local farming, the number of persons working in agriculture is probably greater than what is captured by employment statistics.

As is typical for all the Centro Region, agriculture is dominated by very small farm holdings that have an average of 4.3 ha of utilized agricultural area [9]. In response to the poor bio-physical conditions, sheep grazing is commonplace. Sheep flocks, however, are usually very small with an average of 30 animals [9]. Arable farming occurs more frequently in the floodplains at the northwest and southwest of the region, where, besides pastures and fodder, vineyards, olive groves and cereals are also widespread. Regarding farming systems, the region may be included in the cluster "Natura 2000 area" [72], characterized by extensive subsistence agriculture, with agricultural area being mainly occupied by permanent grassland and meadow and by permanent crops.

High annual temperature variations, with long cold winters and short hot summers, are the main feature of the local climate. The soils, derived from schist or granite, are acidic with low productive capacity. In such context, agro-pastoral systems have been developed as a human response to unpredictability and low productivity, with profound impact in the landscape [73].

\section{Results}

\subsection{Describing the System}

\subsubsection{Identifying the Main Issues}

Socio-ecological systems are complex adaptive systems that integrate multiple interacting components (cultural, political, social, economic, ecological and technological). 
Therefore, a previous point in resilience assessments is to frame the analysis around one or a few related issues that provide focus and direct the process [30]. The main issue may differ depending on the perspective of each stakeholder and may change as the understanding of the system and related issues improves [30]. In this particular case, the abandonment by shepherds is our main issue, since shepherds are crucial actors in the Serra da Estrela agro-pastoral system and the abandonment of sheep farming activities has been noticeable in the last decades, having a huge impact in shepherd's practices, land use and wildfires. Between 1999 and 2019, only, the number of milk sheep and farms with milk sheep decreased about $47 \%$ and $72 \%$, respectively, in the PDO region [9].

The socio-economic disturbances that have recently affected the system, which may also explain the abandonment trend, are other important issues to consider. In fact, in the last four decades, considerably abrupt changes in the system's dynamics took place, mainly as a response to social, economic and political shocks. The establishment of the Serra da Estrela National Park in 1976, the adhesion of Portugal to the European Union in 1986 and the Serra da Estrela cheese PDO recognition by the European Union ten years later, changed the management and governance of the system. New actors with novel approaches, new forms of cooperation and relationships as well as new rules, laws and policies, increasingly controlled by the global liberalized economy and policy, emerged.

\subsubsection{Resilience of What? Key Components of the Socio-Ecological System}

Grazing sheep farming in Serra da Estrela is a system with a long history, dating back to the Roman Empire. The system is characterized by the integration of oaks and shrubs with high altitude permanent semi-natural pastures and milk ewe herds. The Serra da Estrela agro-pastoral system can be defined by its strong interactions between ecological and social components at multiple levels (Figure 2). As described in [74] and following a customary practice in ancient Mediterranean societies [1], the traditional grazing system consisted of the articulation between highland pastures, during dry weather, and low altitude pastures during winter. In the colder months, herds stayed overnight in the stables and grazed in the valleys. In summer, they were taken to the natural pastures that covered the mountain slopes and plateaus and stayed in the fields during the night, inside removable fences, so that the animals, with their manure, could fertilize the soil. The fence was moved every day to ensure fertilization of an extended area. By grazing, the herds helped in vegetation control and forest fires mitigation but often let little space for natural occurring vegetation patterns. Most of the plant communities found nowadays in the mountain are typical of grazed biotopes [75]. One of the most emblematic endemic plants is cervum (Nardus stricta), often mentioned as a driver for milk productivity and cheese quality, particularly by older shepherds.

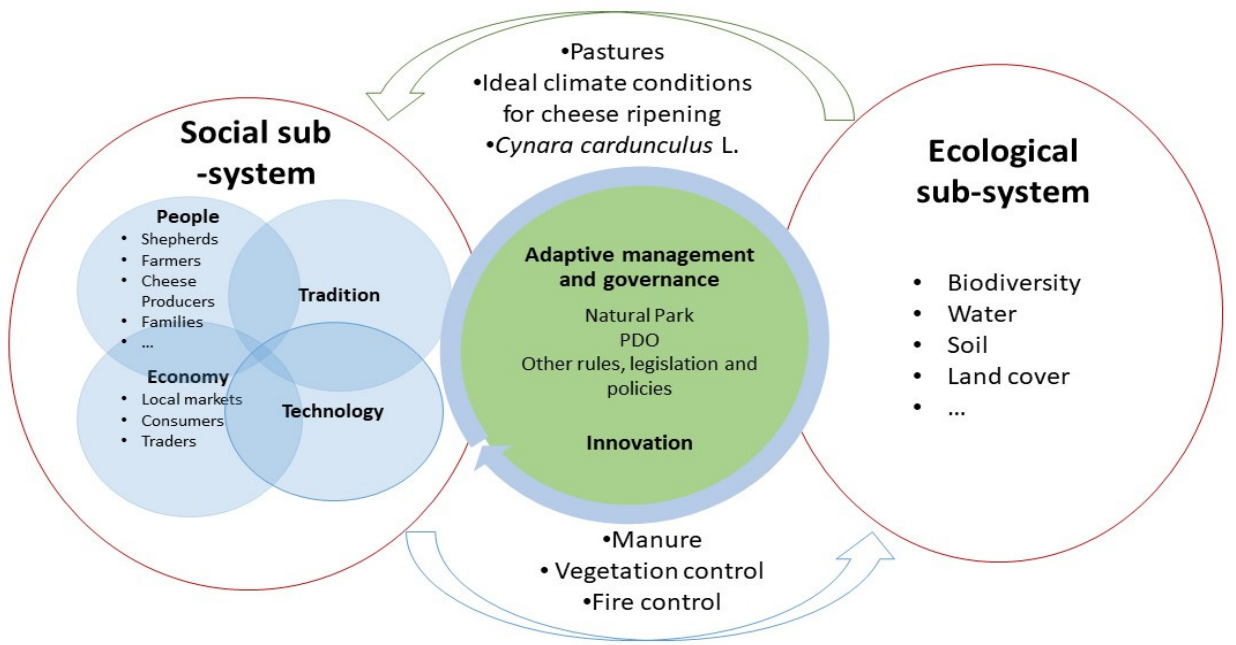

Figure 2. Serra da Estrela agro-pastoral system as a socio-ecological system (Adapted from [76]). 
The whole system is based on local rustic sheep breeds, mainly the Bordaleira da Serra da Estrela, which, although used in milk and cheese production, were mainly explored for wool in the past. However, with the decline of the wool industry, shepherds were forced to rethink the basis of the local economy, by incrementing the production of milk and artisanal cheese. The traditional artisanal cheese is produced only from raw ewe's milk, salt and cardoon flower (Cynara cardunculus L.), which is a spontaneous plant, native to the Mediterranean basin, used in the milk coagulation and proteolysis processes [77]. The harsh winters, with very low temperatures, created the ideal setting for cheese curing, harnessing its distinctive features. The system relied on small family farming with a strong division of labor between men and women. Men were shepherds and women made artisanal cheese.

By focusing on local races, high quality products and traditional production processes, which are closely linked to natural resources, as well as culture and place, shepherds, cheese producers and their families, are crucial actors on the mountain socio-ecological system dynamics.

\subsubsection{Resilience to What? Disturbances, Disruptions and Uncertainty}

In the present section, the main disturbances identified by the participants are summarized, supported by their direct quotes (Appendix A), translated from the original Portuguese.

One of the main disturbances often referred is the proliferation of regulations, regarding compliance with animal welfare, food safety and PDO norms (Table A1). According to participants, the CAP and the entailing European and national legislation, imposes unreasonable technical requirements to shepherds and traditional cheese makers. A shepherd pointed out that animal welfare legislation "should have criteria that match to what existed on the ground" (SH-VR). Regarding cheese making, it is emphasized that there are no significant differences in the requirements regarding artisanal or industrial cheese making. In the cheese producers' opinion, contrary to what happens in other European countries, were traditional products have special treatment, in Serra da Estrela region certain standards are impossible to meet because the requirements that small cheese units have to fulfill are the same "as if they processed forty thousand liters of milk per day" (PDO-H). This is a problem because most "producers are not qualified to meet these administrative and business obligations which increase their costs without adding value" (T-JM). This issue is also relevant in other agro-pastoral systems. In Switzerland, for instance, many people are leaving mountain agriculture as the constraints of farming to the needs of the state increase and small-scale holdings are unable to successfully exploit the new politicaleconomy settings [78]. The same tendency is showed by [79] regarding the Italian Emilia Romagna Region.

The change in CAP direct payments and investment support schemes is also mentioned as an important disturbance. In the past four decades, CAP shifted from price support mechanisms and production orientation to a stronger ecological orientation, based in direct payments [15,42], forcing farmers and landowners to implement adaptive responses. In the general opinion of shepherds and cheese producers, like in other Mediterranean sheep milk farms [6] "direct payments are the pillar that sustains the activity" (SH/PDO-CS; PDO-PP). However, they state, the evolution of direct payments towards a single area payment scheme has hindered the expansion of farms and the installation of new producers, as it discourages landowners from renting their land, causing a property right problem. The failure to get property rights is a relevant issue for the resilience of socio-ecological systems as showed by [80]. Frequently the use of land by shepherds, free of charge or upon payment, is allowed by landowners as long as it does not imply a lease or hand over contract, as this would mean the loss of the respective payment entitlement. As highlighted by one of the shepherds, "nowadays, one of the biggest problems for young people who wants to settle is land, as they can't get lease agreements. Because of subsidies, landowners may even allow them to cultivate butt this is not enough to legalize animals because they have no legal documents proving they are tenants" (SH-VR). The result is that shepherds, who 
effectively use the land, not only do not receive the direct payment, but also cannot include these properties when applying for agricultural investment support measures. Ambiguous effects of the CAP were also reported in other Mediterranean pastoral systems [5] where the subsidies payment tools and rules has generated perverse effects with negative impacts on land-management practices. The withdrawal of animals from the investment support schemes is also a reason pointed out by the participants for the decrease in the number of shepherds and artisanal cheese producers in Serra da Estrela region (Table A2).

Another main shock often mentioned is the establishment of a strong dairy industry in Serra da Estrela region, producing an industrial type of cheese that often competes with traditional manufactured cheese, since tourists, visitors and consumers in general are often misled, as they are not (or are poorly) aware of the differences between the two types of cheese. Unable to identify the genuine Serra da Estrela cheese, consumers often decide based on price, which is much lower when it comes to industrial cheese. In fact, a recent online survey of Portuguese consumers showed that only $30 \%$ of respondents who declared to know PDO cheeses are actually able to clearly identify PDO cheeses on the market [81]. In addition, some industrial brands adopted the name of places in the mountain (e.g., Seia), leading consumers to link industrial cheese with the territory. This setting had a strong negative impact on the valuation of traditional cheese, whose price has remained almost unchanged in the last 30 years. The opposition between industrial dairy producers and farm producers is not a prerogative of Serra da Estrela DOP. In several French cheese DOP a similar debate is taking place [82]. Some of the most relevant opinions of participants regarding this topic are displayed in Table A3.

The ageing and depopulation in Serra da Estrela region, with special emphasis on rural areas, is also identified as one of the main shocks. Depopulation not only reduced labor availability, but it also weakened the human presence in the mountain, which is perceived by participants as one of the main causes for environmental degradation and strong forest fires. According to the participants, "whether or not there is people in the mountains makes a big difference in fire control" $(\mathrm{CH}-\mathrm{H})$ because "the main firefighters are the animals and the population in the territory" $(\mathrm{SH}-\mathrm{H})$. This trend and its consequences are common to most agro-pastoral systems in southern Europe [3-6].

Regarding labor availability, the unanimous opinion is that shepherd's hard work, often underpaid and socially unrecognized, is not attractive to the few young people who remained in the mountain villages because they have greater expectations than the previous generation (Table A4). The opportunity cost of labor and higher perceived working conditions in other economic sectors and even in other agricultural activities, reduces the attractiveness of sheep milk and cheese production. The participants' perception is that "everyone is giving up" because "there are easier jobs, a cleaner life, a more peaceful life and nowadays everyone want that" (SH/CH-AF). For example, in Italy, despite the important economic, social and environmental roles played by shepherds, their living conditions as well as economic benefits and social rights are often discouraging [3]. The lack of generational turnover is one of the major threats to the system, following the same trend of other agro-pastoral systems in southern Europe [6] and small family businesses in general [83]. Besides this, almost all shepherds and traditional cheese makers who participated in the study stated that they do not wish this kind of life for their children, "not because of prestige, but because it is a hard life" (SH/PDO-CL).

Like in numerous mountain socio-ecological systems around the world [5,11,15,42], climate change is also identified as a source of disturbance in the Serra da Estrela agropastoral system. Table A5 shows the more relevant statements of participants regarding the impacts of climate change in pastures management and cheese quality. Particularly stressed by the participants are the extreme climatic conditions, currently more frequent, and their effect on water availability. Extreme droughts have strong impacts on feed availability, forcing irrigation. However, as stated by the shepherds, the streams carry less and less water every year. On the other hand, global warming has led to a greater incidence of forest fires and the degradation of natural and cultivated grazing areas. The impact 
of climate change in cheese quality is also mentioned by some participants. In the past, they say, the best cheese was January cheese because the ideal temperature and humidity conditions were present. According to participants it is unthinkable nowadays to make cheese without a cheese ripening chamber that can guarantee a good artificial environment for cheese ripening.

The impact of a world being more and more technological, more global and liberalized, dominated by multinationals and large retail companies is also recognized by several participants (Table A6). "Local markets are over; there are no more fairs" (SH/CH-AA); "there is no scale and it's impossible to reach modern distribution channels" (M-H). In such a context, they claim, scale increase and international wealthier markets access are crucial. Mainly those who arrived more recently to the system, agree that Serra da Estrela cheese is a gourmet product, to be consumed occasionally between friends and family and that it must be brought to markets willing to pay for this specificity. In addition, the low purchasing power in Portugal constraints Serra da Estrela cheese consumption at local and national level. "Serra da Estrela cheese is, in fact, more and more an export product, which is a paradox: the people who produce it cannot afford it" (C-H).

The prevalence of liberalization was highlighted by participants not only in the Economy but also at the policy making level. After de adhesion of Portugal to the European Economic Community (EEC), many services provided by the state have been transferred to the private sector. This was the case of rural extension services that went from the ministry of agriculture to producer organizations. However, after a few years of financial support from the EEC, several producer organizations collapsed, letting farmers with no technical advice. "In the past, the public services had rural extension brigades" that nowadays are "mainly filling applications to direct payments" (T-RC). In more dynamic and market oriented regions of the country, private companies now provide this kind of advice but not in more remote areas and not to smaller and poorer farmers. This bottleneck is also pointed out by farmers as an important disturbance in the agro-pastoral system in Serra da Estrela in the last decades (Table A7).

\subsection{The System Dynamics}

In view of the disturbances described in the previous subsection, Serra da Estrela's shepherds and traditional cheesemakers had to adopt strategies to enhance socio-ecological resilience, mainly by social learning through experimentation and innovation. The most disturbing technical innovation was the replacement of Bordaleira breed by foreign breeds, mainly Lacaune. As pointed out by one of the participants, "sheep breed is the most serious problem in Serra da Estrela cheese production" (T-CH). The industrial cheese only marginally includes Bordaleira milk and the increase in demand for nonspecific sheep's milk led to an increase in its price. Many shepherds adapt to this change by replacing Bordaleira breed with more productive foreign breeds, strangling the production of certified cheese, which mandatorily relies on Bordaleira milk.

Several technological innovations aimed at reducing the needs of labor were also adopted, both in milk and cheese production processes. In the case of shepherds, the replacement of pastoralism in the open field by fenced pastures, is the most often referred innovation. Such process was made possible, between other things, by rural depopulation and increased availability of lowlands pastures, allowing shepherds to end summer transhumance. "Winter transhumance ended at the beginning of the 20th century and summer transhumance ended at the end of the 20th century. Today very few herds go to the top of the mountain to eat Nardum stricta" (T-JM). "There are practically no sheep in the mountain nowadays" (T-AC). Nevertheless, participants recognize that this strategy may affect cheese quality, since sheep eat other and less diverse plants. Mechanical milking also had a strong impact in labor saving, even though the majority of shepherds still milk by hand, because, they say, until recently the machines were not well calibrated for sheep. This kind of dynamic is present. 
As for the cheese manufacture, some equipment modernization and new procedures have been adopted, increasing labor productivity. Examples are the diffusion of small technologies that replace repetitive and time consuming tasks such as pressing, milk stirring and temperature measurement. The widespread adoption of cheese ripening chambers mitigated the impact of climate change on cheese production. It even allowed some producers to make cheese throughout the year and not just in the traditional season that lasted, roughly, from December to April.

Regarding milk production, however, no effective strategies were developed in order to cope with decreasing water availability. Some shepherds now irrigate a part of their pastures and have increase hay production. However, irrigation is not possible everywhere and it is costly. Therefore, producers tend to reduce it to a minimum scale. Some illustrative participant's statements regarding the adoption of technic innovations are displayed in Table A8.

The more striking changes were, however, of a social nature, being specialization of farms one of the most visible trends (Table A9). As said before, the traditional system is defined by its family character and a strong labor division, in which, typically, the man was the shepherd and the woman was the cheesemaker. Artisanal cheese production disconnected from sheep farming was not common. Currently, on the contrary, artisanal cheesemakers often do not have sheep. They buy the milk from shepherds who, in turn, do not produce cheese. At the same time bigger certified cheese factories, managed by external actors, strongly connected, with a different way to make business, are arriving to the territory. Although these units respect the PDO specifications, they do not produce at an artisanal scale and hire labor for cheese making. While maintaining the essential of the artisanal techniques of the past, cheese is now produced in a larger scale in factories where the family character is no longer present and standardization is the target.

Several marketing innovations were also pointed out by participants (Table A10). In order to satisfy the preferences of urban consumers and respond to the decrease in purchasing power, the PDO specifications regarding the size of the cheese have been changed. Before, certified cheeses should weight no less than $1 \mathrm{~kg}$ but, currently, the weight can go down to $500 \mathrm{~g}$. According to the participants, big retailers started demanding for smaller units so that consumers do not have to pay so much per unit. The introduction of a casein mark was also an innovative procedure, intended to increase traceability and protect consumers as well as cheesemakers from unfair commercial practices and competition by the cheese industry. The diversification of market chains was another relevant innovation. As an example, Serra da Estrela cheese is now used in new culinary recipes for tourists in the largest cities in the country.

\subsection{System Interactions and Governance}

The system governance structure includes four interacting management levels: European (Common Agricultural Policy, European legislation), national (Government and national policies), regional (Serra da Estrela National Park (PNSE), producer's organizations and regional authorities) and municipal (local authorities). Through the implementation of $\mathrm{CAP}$, the European Commission plays a major role in the system resilience, mainly through direct payments and investment support measures. In addition, European regulations and directives regarding food markets and food safety have a strong impact in national agricultural and food legislation. The Food and Economic Security Authority (ASAE) monitors the shepherds' and cheesemakers' compliance with regulatory legislation and assesses the risks in the food chain.

At the regional level, the PNSE Land Management Plan establishes limits to the usage of the territory by economic activities in order to protect and preserve the park natural resources and values. Although the PNSE is a regional organism, it is controlled by a national government institute (ICNF-Nature Conservation and Forest Institute). The main sector producer's organizations in the region are Estrelacoop—Serra da Estrela Cheese Producers Cooperative, to which all certified cheese producers must belong, and ANCOSE-Serra da Estrela Sheep Breeders National Association. Besides the marketing of Serra da Estrela 
cheese, the main roles of Estrelacoop are the monitoring of the PDO certification process, the linkage between producers and the certifying entity-Beira Tradição—and to provide technical support, mainly in the implementation of HACCP (Hazard Analysis Critical Control Points), to those who wish to become PDO producers. The purposes of ANCOSE are the selection of Serra da Estrela Bordaleira breed, sheep products typifying and, in a general way, the promotion of Bordaleira breeder's welfare. ANCOSE closely works with central government agencies regarding, for instance the regional implementation of the national animal health plan. The local authorities, at the municipality level, have an important role regarding cheese shops licensing and, more recently, cheese certification support.

Sometimes, at the technical level some collaboration exists between Estrelacoop and other stakeholders, namely, municipalities, but, generally speaking, the cooperation and interactions among agencies and between agencies and producers are quite fragile. Most producers feel they are not represented in their organizations and claim it is not worthy to be involved and join the organizations governing and decision bodies. Regarding government agencies, participants claim that their main functions are regulation and inspection. From their point of view, technicians, as well as the rules and obligations they impose, are a long way from the real world experienced by producers (Table A11). This lack of networking becomes even more noticeable when it comes to the relationships between producers. The decrease in the number of shepherds and cheesemakers, the disappearance of cheese producer's markets, as well as the loss of several gathering traditions, such as transhumance, left small room for the producer's interactions.

\subsection{Synthesis of Results}

Based on participants' statements it is clear that the interactions between the social and the ecological subsystems in Serra da Estrela agro-pastoral system are blurring. The natural resources in the mountain are no longer part of the system, with producers replacing the open field pastoralism by fenced pastures and the transhumance by irrigated pastures. Pasture and forage breeding systems are taking over from the traditional pastoral system and Bordaleira breed has been partially replaced by more productive breeds. This change, as mentioned by the participants, has a strong impact on vegetation, mountain habitats and the occurrence of fires, being very similar to what happens in several agro-pastoral systems in the southern Europe.

The question remains as to whether or not this new system configuration is more resilient than the previous one, since contradictory trends can be observed. As stated earlier in this paper, five main factors may be used to assess rural resilience: diversity in agents and interactions, modularity, social capital, overlap in governance and innovation. Table 1 summarizes the results presented in the previous subsections and shows how these factors have evolved along the earlier described dynamic of the Serra da Estrela socio-ecological system and how they affected resilience at different levels of the system. 
Table 1. Resilience trends at different levels of the Serra da Estrela agro-pastoral system.

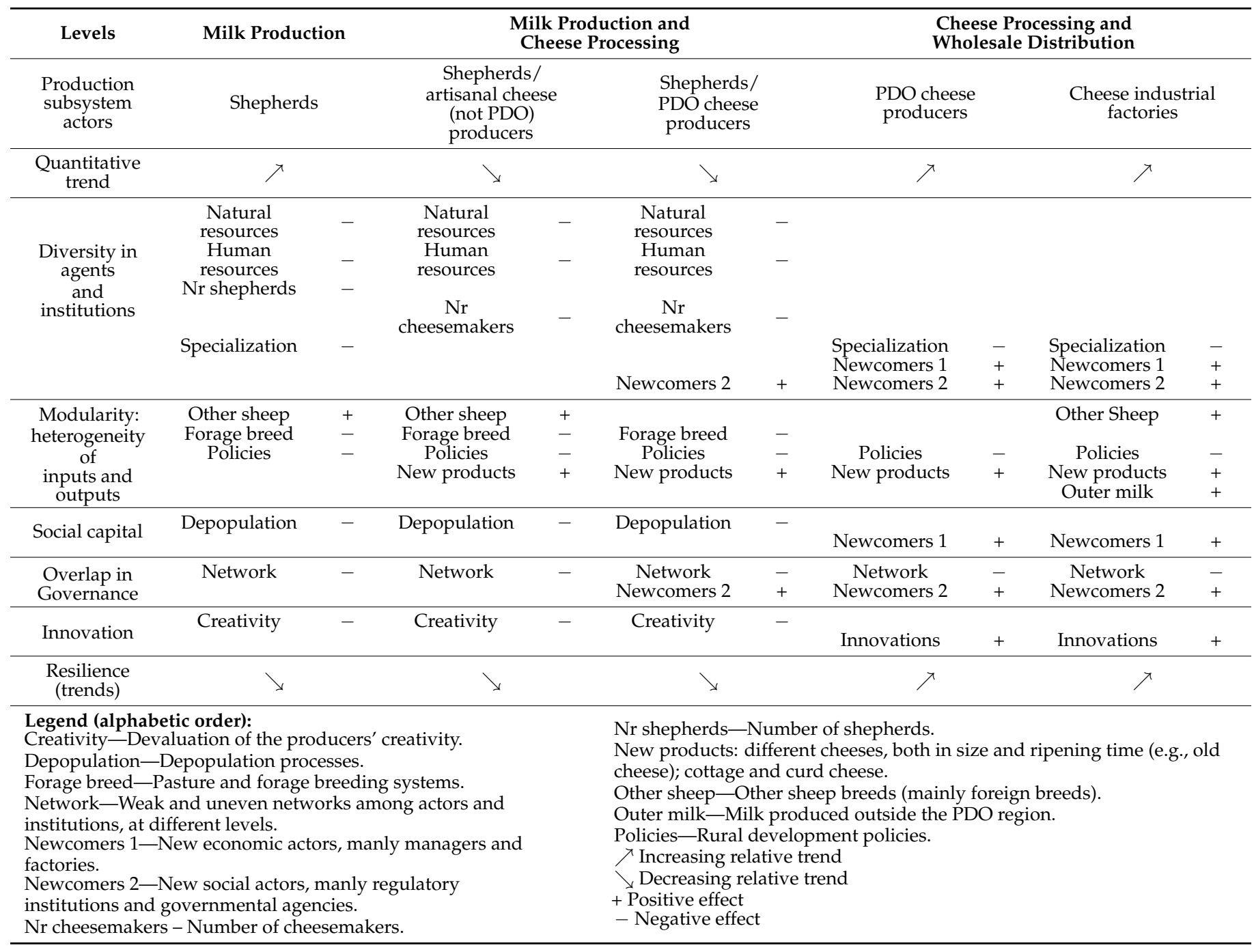

\section{Discussion}

Like in other studies focusing on the resilience of SES with emphasis in the social subsystem $[2,5,46,84,85]$, we used in-depth interviews with different groups of stakeholders to build a conceptual model enabling us to better understand the causes, the effects and the endogenous and exogenous factors that have changed people's behavior and the structure in the Serra da Estrela agro-pastoral system. For this purpose, we qualitatively analyzed the structure (variables, relationships and feedbacks) of this SES from the local community's point of view. As stated by [86], this type of approach acknowledges people's empirical, social-ecological behaviors and, at the same time, addresses the values and meanings through which they interpret those behaviors and systems.

Thus, considering the "resilience of what to what" question, we focused on the resilience of the Serra da Estrela agro-pastoral system mainly to social, political and economic disturbances. Generally speaking, our results confirm the findings of other studies on agro-pastoral systems. In a recent review and meta-analysis study comprising case studies around the world [2], socio-economics (e.g., access to markets, economic transition), policies, access to services, land access and abiotic factors (e.g., drought, fire, climate change) were found as the most common drivers of change in pastoral systems. Regarding Europe, socio-economics, policies-at local, national and international levels-and sociodemographic, including, among others, ageing, depopulation and unemployment, were the most relevant factors. As we have shown above, these factors were also mentioned by 
the participants in the present study as the main disturbances to which they had to adapt in order to persist, even though some critical changes had occurred in the system.

Similar to that in Italy [3], the Serra da Estrela agro-pastoral system shifted to intensive rearing in stables, leading to the abandonment of some grazing areas as well as of marginal cropped fields. The same trend is described by [4] regarding Large Scale Grazing Systems in Greece, Italy and Spain. Several French mountain regions have also lost population over the last decades as well as breeding activities and transhumance practices [5]. In a comprehensive participatory assessment of sustainability in sheep farming systems in north eastern Spain, local stakeholders remark the disappearance of grazing practices and sheep flocks, particularly in mountain areas, the changes in vegetation and landscape, and the increase in risk of fire hazards. In a study regarding biodiversity conservation in Mediterranean grazing systems [7], the abandonment of mountain pastures by shepherds and its impact on the vegetation is also highlighted.

Another important trend in Serra da Estrela is the exclusion of local communities from the system dynamics, in the sense that the new vision is based on quantity, standardization, semi-industrialization and export to other regions in the country and in the world, where consumers are willing to pay high prices for quality food. As showed by [79], regarding the case of Parmigiano-Reggiano PDO, the effect of innovations and market evolution in the structure of the production systems and the territory is not neutral, since the value chain is embedded in the territory and, therefore, the sustainability of the value chain affects the sustainability of the territory and vice versa. In Serra da Estrela, like in other places [55], one of the consequences of market expansion has been that businesses have become less integrated with the local economy, the social community and the territory. The ecological sub-system is now less relevant to income and have been subject to neglect, while market conditions have become more important. In order to be competitive in the market, the Serra da Estrela agro-pastoral system became more concentrated (fewer farms but more animals per farm) and specialized (milk production or cheese production), following a trend also visible in other agro-pastoral systems [5]. It is worth noting that, more than other alternatives, this intensification and specialization is encouraged by new agents in the advisory system [87].

In other words, the Serra da Estrela agro-pastoral system has moved from a local agroecological system to an increasingly complex system, in which the ecological sub-system and the local communities have been neglected. External markets now play a central role, at least in stakeholder's discourse, with new strategies being mainly based on the product. The product is defended, but not the natural and social territory that created it. It seems that, regarding the three types of dynamics earlier presented (persistence, adaptability and transformability), the system is not persisting or adapting but rather irreversibly transforming, moving in to a new trajectory controlled by different variables, with different structural and functional properties.

In the present case, regarding diversity in agents and institutions, at a more macrolevel, new actors are arriving, with new ideas and connections increasing the system diversity, mainly at cheese processing and distribution levels. At the same time, human and natural resources become less relevant, because the standardized resources used by these new production units are weakly linked to the environmental characteristics, like biodiversity and animal breeds, as well as with local tradition, jeopardizing the system specificity. Besides this, the system has moved towards concentration with less shepherds and cheesemakers but more animals per farm and higher average cheese production. At a micro-level, within the farming system, specialization is a growing trend that reduces diversity. Shepherds and cheese makers are becoming separate entities, and industrial PDO cheese factories, which hire labor, are replacing small and diverse family units. Thus, it seems that while the diversity of the system has decreased at the agricultural production (primary) level, it has increased at the downstream levels, both in processing and distribution. 
Closely related to diversity is modularity. Following [14], the main force driving modularity in a socio-economic context is the heterogeneity of inputs and outputs. In the case of Serra da Estrela's cheese producers, the diversification of actors, with different demands, may have increased the system modularity. For instance, at the input side, while PDO cheese producers have to use Bordaleira milk, non PDO artisanal cheesemakers and industries may use milk from other breeds and other places. Further, at the output level, nowadays the PDO legislation allows for a greater variety of cheese, both in size and ripening time. Regarding shepherds, however, the inputs heterogeneity is narrowing, since the increase in forage area is replacing the permanent "natural" grassland which shaped the interaction between ecosystems and agro-pastoral activities from millennia. On the other hand, rural development policies, by supporting "ideal" farms structures through subsidy programs, may lead to a decrease in modularity because homogenization of these structures is promoted and producers who do not exactly comply with the legal rules are excluded from the system. This is clearly the case of Serra da Estrela's shepherds that have no property rights over land even if they use it. Altogether, while modularity has increased in cheese making, it has decreased at shepherds' level.

Regarding social capital, the depopulation processes have undermined the traditional way of life of shepherds in Serra da Estrela and their local institutions. The young often migrate and the newcomers, that are usually wealthier and better connected than local people, took over representative institutions like cooperatives and associations, in order to protect their own interests. At the same time, while at an individual level shepherds and cheese makers were able to adapt to changes by flexibly organizing the family work, changing the structure of animal production and adopting new technologies, they showed, however, a small ability to engage in collective action. For these actors it was not possible to build social relationships based on trust, reciprocity and co-operation that, as stated by [79], are the glue of local action and an endogenous development mechanism.

Overlap in governance and networks that encompass local, regional and national levels of governance is recognized by several authors as vital for resilience $[28,30,55]$. However, in Serra da Estrela the links between the different scales have become weaker and uneven. Using the typology of local agro-food systems suggested by [79], the agro-pastoral system in Serra da Estrela is becoming more open in the sense that sheep milk is no longer mainly processed by local producers and purchased by local consumers but is more and more characterized by the presence of other actors that do not necessarily belong to the territory. This process could promote a closer relation to local and non-local organizations and government agencies, allowing innovation and new technological paths, while raising competitiveness and preserving local traditions. However, that is not what we have found.

Concerning innovation, the role of a producer's creativity and imagination is undervalued. The engineering approach [56], that looks at farms as devices to exploit economies of scale and scope as a response to technological progress, still dominates the perspectives of government agencies, producers organizations and, most of all, newcomers in the sector. At the same time, learning systems whose survival and growth strongly depend on the successful generation and integration of new knowledge are neglected. Shepherds and traditional cheesemakers do not feel recognized as equal co-authors of the knowledge generation. Informal knowledge is being neglected in the innovation processes leading to product standardization and loss of excellence.

All in all, the results show that the traditional Serra da Estrela agro-pastoral system is collapsing with "major losses of social, human, and natural capitals" to use one of the clearest definitions of social-ecological collapse in the resilience literature [88]. From the 14 mechanisms identified by [40] that may lead to collapse in SES, four are dominant in the Serra da Estrela agro-pastoral system: (1) specialization and diversity loss; (2) scales of governance, production and regulation misalignment; (3) getting resources (e.g., animal breeds and sheep milk) remotely; and (4) loss of modularity and reliance on connections. The results do not allow, however, to categorically conclude if this new architecture is more or less resilient than the previous traditional one. In fact, as we have seen, several trends 
can be observed regarding each one of the resilience domains and the different system levels and actors. The focus on actors highlights that the question should not just be "the resilience of what to what?" but also "whose resilience?" and "who decides?" [89], as well as "who benefits". As this study shows, the ability to change and the impact of change is not evenly distributed between all the system actors and levels, thus raising issues of justice and power.

\section{Conclusions and Recommendations}

In this study, the Resilience Assessment Framework [30] was applied as a methodology for analyzing the agro-pastoral system of Serra da Estrela from the perspective of various actors. The main finding is that the system is irreversibly transforming, moving into a new development trajectory, with new actors and opportunities being explored. Whether or not this new trajectory will improve the living conditions of local communities, by creating jobs and reducing work hardship, is a question which the present research is not able to answer. What is clear is that Serra da Estrela agro-ecological system is following a trajectory leading to something completely different from the pastoral system that dominated Serra da Estrela in the past centuries.

As evidenced in the study, the dynamics of the system have been largely influenced by policy measures and this influence may be expected to continue in the future. In fact, as showed in the results section, many public services, such as extension-related services, are no longer provided by the government, leaving small-scale farmers dependent on private inputs' suppliers. On the other hand, some small-scale producers are unable to successfully meet the new challenges arriving from the proliferation of regulations (e.g., regarding compliance with animal welfare, food safety and PDO norms). Consequently, small-scale producers are now more dependent and vulnerable to new market rules. Finally, CAP direct payments and investment support schemes prove not to be suited for the local producers' needs. Moreover, looking at the implementation of these policy measures, there is no indication that their trajectory will change significantly, neither at European nor national level.

Some of these policies have eroded the resilience of shepherds and farmhouse cheese makers and reinforced maladaptive responses. Therefore, the design of new policy measures able to solve the main issues identified by local actors, could encourage and support the traditional agro-pastoral system and, at the same time, mitigate natural resource degradation. Relying on participants' perspectives two main policy changes should be implemented. The first one is the integration of different types of land property rights on the CAP rules regarding direct payments and investment support measures. The second is the design of national animal welfare and food safety regulations adapted to different scales of production and income so that the costs of compliance are bearable by producers.

It has also become clear that the profitability of the system, in particular milk production, can only be achieved by subsidizing production. In this context, modulating direct payments according to herd size, increasing it for smaller herds, may be justified if the main objective is not the economic profitability of the system, but rather the preservation of a more acceptable population density and the maintenance of the ecosystem services provided by the shepherds and their flocks.

On a different level, collaboration and communication between actors must be enhanced. The cooperation among producers would allow for the establishment of common goals and for the progression of advocacy in order to increase state recognition of the roles of shepherds and artisanal cheese producers in Serra da Estrela and other mountain regions. On the other hand, the creation of platforms for multilevel communication, connecting a range of public and private actors, would close the gap between different kinds of knowledge and backgrounds, allowing us to shape extension programs tailored to the system's needs, thus stimulating learning and innovation.

Another recommendation is to intensify public and private educational and communication strategies to clarify for consumers the differences between industrially produced 
cheeses and PDO cheese. This communication should point out not only the differences in the intrinsic characteristics of the products but, above all, the differences in the respective production systems and their implications in terms of sustainability, particularly social and environmental sustainability, and maintenance of biodiversity.

While this study provides interesting insights on the resilience of agro-pastoral systems, we are aware of its limitations. As a qualitative case study it cannot be generalized and, therefore, the results should be read cautiously. Moreover, this analysis was limited to a retrospective on the evolution of the system, without proposing the necessary management strategies to increase its resilience. On the other hand, the study paid special attention to the dynamics of the traditional system of cheese production, without delving, however, into the links with more recent and mass forms of production. In fact, the industrial cheese factories, whose production is quantitatively predominant in the region, was presented more as a counterpoint to traditional production, but its dynamics was not analyzed by itself. Thus, we were able to conclude that industrial production constitutes a competitive threat to traditional production, but we can conclude nothing about the possible participation of this type of industry in the development processes of the region and its contribution to the well-being of the local population.

In future research on the subject, a more global and integrative approach is suggested, where the sustainability of the different production subsystems should be analyzed. In particular, the impact of the new actors attracted to the system should be analyzed and the extent to which they can transform the system without it collapsing should be assessed. Another suggestion is to establish comparative analysis with other cheese production systems in the Centro Region of Portugal, with other regions of the country and other European countries.

Author Contributions: Conceptualization, I.D. and O.S.; methodology, I.D.; data collection, I.D. and O.S.; formal analysis, I.D.; writing — original draft preparation, I.D.; writing—review and editing, O.S. All authors have read and agreed to the published version of the manuscript.

Funding: This research was funded by the QCLASSE Project: Characterization and Valuation of the Authenticity of QSE PDO and its vocation for Health Promotion (COMPETE 2020).

Institutional Review Board Statement: Not applicable.

Informed Consent Statement: Informed consent was obtained from all subjects involved in the study.

Data Availability Statement: The data presented in this study are available on request from the corresponding author.

Acknowledgments: The authors would like to express gratitude to all the people that kindly agreed to be interviewed, making this research possible.

Conflicts of Interest: The authors declare no conflict of interest.

\section{Appendix A}

Table A1. Participants illustrative statements regarding the impact of PDO and food safety norms.

\begin{tabular}{cc}
\hline Participants & Statements \\
\hline SH/PDO-CS & $\begin{array}{r}\text { My grandmother had a cheese shop, which was like a kitchen, with a chimney } \\
\text { and two curing rooms. It had wooden shelves and already had a bathroom. } \\
\text { Then all this demands started ... }\end{array}$ \\
T-CH & $\begin{array}{r}\text { Legislation forced producers to tile the walls and to remove aluminum; } \\
\text { everything is now made of stainless steel; wooden spoons and wire scouring } \\
\text { pads were forbidden. }\end{array}$ \\
\hline
\end{tabular}


Table A1. Cont.

\begin{tabular}{|c|c|}
\hline Participants & Statements \\
\hline $\mathrm{SH} / \mathrm{CH}-\mathrm{AF}$ & $\begin{array}{l}\text { Many people were reluctant because they did not understand why so many } \\
\text { changes were needed. First there were tiles, then it was painting; some came } \\
\text { and said one thing, others came and said something else. The technicians } \\
\text { themselves did not all have the same idea; it seems that they read the laws } \\
\text { differently. Those requirements, so abrupt, should have been more light, } \\
\text { taking people more calmly, more slowly, so that people could change but } \\
\text { without bitterness. }\end{array}$ \\
\hline SH/PDO-CL & $\begin{array}{l}\text { There are no differences (in requirements) between this type of cheese and the } \\
\text { large industry. I think this is different for other European colleagues. When a } \\
\text { European directive comes out, in Portugal it is applied to detail. People bring a } \\
\text { copy and apply everything here. There are certain rules that are impossible to } \\
\text { meet. In other European countries, namely in France, for this type of } \\
\text { traditional products the directives are the same as ours, I think, but on the field } \\
\text { there are differences. }\end{array}$ \\
\hline $\mathrm{H} / \mathrm{PDO}$ & $\begin{array}{l}\text { A guy gives up before reading Decree-Law } 75 \text { of } 11 \text { May } 2015 \text {, which I already } \\
\text { know by heart. I spent } 48 \text { h with nine entities before opening the door. The } \\
\text { starting motivation is destroyed by all the challenges and obligations we have } \\
\text { to fulfill. }\end{array}$ \\
\hline T-PM & $\begin{array}{l}\text { The cheese making facilities problem is now peaceful. (In the past) it was hell: } \\
\text { put a door, put a window ... it was chaos ... that ended. Now there are } \\
\text { typical facility plans ... The problem (now) is livestock farms licensing. Now } \\
\text { the law says you must have a place for animals that meets animal welfare } \\
\text { requirements... all on top of the producer. The producer doesn't care anymore! } \\
\text { This is the biggest problem causing erosion in the activity. }\end{array}$ \\
\hline T-JM & $\begin{array}{l}\text { Today there is a new affront which is REAP (Livestock Regime Activity) (...) } \\
\text { The farms must fulfil a set of rules regarding equipment and other structures } \\
\text { that provide animal welfare and we know that these families are poor. The } \\
\text { same happened in the past in cheese shops: it was mandatory to build a } \\
\text { bathroom in the cheese shop, which they did not had at home. Then, the } \\
\text { cheese shop bathroom became the family bathroom. People's homes are not } \\
\text { important, but animals must live in good conditions... }\end{array}$ \\
\hline SH-VR & $\begin{array}{l}\text { The ministry of agriculture imposes a lot of bureaucracies. An example is } \\
\text { REAP. We always had our facilities, and REAP should have criteria that match } \\
\text { to what existed on the ground; it gives the impression that it was invented by } \\
\text { people who never dealt with animals. }\end{array}$ \\
\hline SH-RP & $\begin{array}{l}\text { They demand everything and anything. There are things that can be tolerated, } \\
\text { but others ... Now they want us to have a refrigerated van to take the milk to } \\
\text { the dairy ... They even demand that we have a bathroom in the mechanical } \\
\text { milking parlor. }\end{array}$ \\
\hline SH/PDO-CL & $\begin{array}{l}\text { I was in a meeting } 2 \text { or } 3 \text { years ago where we were asked to build tanks for } \\
\text { wastewater treatment, with a size that is unaffordable for us here. I don't know } \\
\text { if it the legislation came out, because nobody did it. }\end{array}$ \\
\hline T-JM & $\begin{array}{l}\text { Producers are not qualified to meet these administrative and business } \\
\text { obligations which increase their costs without adding value. }\end{array}$ \\
\hline
\end{tabular}

Table A2. Participants illustrative statements regarding the impact of CAP changes.

\begin{tabular}{|c|c|}
\hline Participants & Statements \\
\hline T-JM & There is a problem of land use and property rights. \\
\hline T-PM & In fact, there is available land but the legal access to it is limited. \\
\hline $\mathrm{SH}-\mathrm{H}$ & $\begin{array}{l}\text { It is very difficult for a young farmer to install, using EU subsidies, when there } \\
\text { is no written land lease agreement. }\end{array}$ \\
\hline $\mathrm{T}-\mathrm{CH}$ & $\begin{array}{l}\text { Landlords do not make lease agreements and therefore shepherds are not able } \\
\text { to apply for payment entitlements; in this case the land does not count for } \\
\text { subsidies or herd increase, nothing. }\end{array}$ \\
\hline SH-SA & $\begin{array}{l}\text { We pay rent but they don't sign anything; they receive the rent and the subsidy. } \\
\text { Without a contract, anything can be done. }\end{array}$ \\
\hline
\end{tabular}


Table A2. Cont.

\begin{tabular}{|c|c|}
\hline Participants & Statements \\
\hline SH-VR & $\begin{array}{c}\text { Nowadays, one of the biggest problems for young people who wants to settle } \\
\text { is land, as they can't get lease agreements. Because of subsidies, landowners } \\
\text { may even allow them to cultivate... But this is not enough to legalize animals } \\
\text { because they have no legal documents proving they are tenants. }\end{array}$ \\
\hline SH/PDO-CL & $\begin{array}{l}\text { The direct payments were simplified but I don't know how fair it is to only } \\
\text { base it in land area; some landowners get as much subsidies by doing almost } \\
\text { nothing as those who cultivate the land and have costs. That is why we have } \\
\text { so much abandoned land here. If things were different, maybe larger areas } \\
\text { could be used by shepherds. }\end{array}$ \\
\hline T-RC & $\begin{array}{c}\text { How can meadows be installed if the land is not held by shepherds? At most } \\
\text { annual pastures can be installed. }\end{array}$ \\
\hline T-JM & $\begin{array}{c}\text { In the last } 3 \text { Rural Development Programs, the purchase of animals was } \\
\text { removed from the investment support schemes. Then, how can new people } \\
\text { settle in? If you do not own the land, if there is no support to buy animals, how } \\
\text { will you settle? }\end{array}$ \\
\hline
\end{tabular}

Table A3. Participants illustrative statements regarding the impact of dairy industries.

\begin{tabular}{|c|c|}
\hline Participants & Statements \\
\hline $\mathrm{T}-\mathrm{CH}$ & $\begin{array}{l}\text { For those who live in big cities, a cheese produced in Seia is the same as Serra } \\
\qquad \text { da Estrela cheese. }\end{array}$ \\
\hline $\mathrm{SH} / \mathrm{PDO}-\mathrm{H}$ & $\begin{array}{l}\text { Any person who comes here sees Serra cheese everywhere. But it is not real } \\
\text { Serra da Estrela cheese. It is a cured sheep cheese, probably made in an } \\
\text { industrial factory, with milk coming from Spain (...) It cannot be called Serra da } \\
\text { Estrela cheese. People must learn to identify the differences. Is Serra da Estrela } \\
\text { cheese more expensive? Yes, it is! I have more production costs per kilo than } \\
\text { industrial factories, so it has to be more expensive. }\end{array}$ \\
\hline $\mathrm{SH} / \mathrm{PDO}-\mathrm{CL}$ & $\begin{array}{l}\text { I receive a lot of people from Lisbon and other places here at home. They } \\
\text { arrive and ask: what is the price of your cheese? When I tell them it's } 17 \text { euros, } \\
\text { they answer that they can find Serra cheese at } 12 \text { euros in supermarkets. I ask if } \\
\text { it is real Serra da Estrela cheese and they answer that it has the Seia label. We } \\
\text { must explain that it is not Serra da Estrela and show the differences. The } \\
\text { industries use names like Seia to deceive consumers. }\end{array}$ \\
\hline M-JA & $\begin{array}{c}(\ldots) \text { the intention is to mislead the consumer because they call it Seia but } \\
\text { often the cheese is not even made in Seia. }\end{array}$ \\
\hline T-JM & $\begin{array}{l}\text { Since the name Seia is linked to Serra da Estrela, people think they are buying } \\
\text { Serra da Estrela cheese. Sometimes, it's not even done in Serra da Estrela. }\end{array}$ \\
\hline PDO-PP & $\begin{array}{l}\text { It is not illegal; (industrial cheese) is a regular cheese sometimes mistaken with } \\
\text { Serra da Estrela cheese. It's when someone promotes this misunderstanding, } \\
\text { that a crime is committed. This happens all across the region, up the hill, in all } \\
\text { those shops claiming to sell Serra da Estrela cheese, when what they actually } \\
\text { sell is industrial cheese. That's how they make their profit. }\end{array}$ \\
\hline $\mathrm{T}-\mathrm{AC}$ & $\begin{array}{l}\text { People buy what is cheapest; supermarkets sell sheep cheese from the factories } \\
\text { in Seia. Most of the sheep's milk comes from Spain. The organoleptic qualities } \\
\text { of milk are completely different and the cheese taste is completely different, } \\
\text { although they throw cardoon flower and say it is made by hand... } \\
\text { (... ) (industrial cheese) is made with hay and feed, because the animals are } \\
\text { inside the stable; they just come outside for a walk, because outside there is } \\
\text { nothing to eat. They may even taste very similar. The flavor can be built. In the } \\
\text { factory, people know what to add to cheese in order to get the flavor they want. }\end{array}$ \\
\hline
\end{tabular}


Table A4. Participants illustrative statements regarding the impact of ageing and depopulation.

\begin{tabular}{|c|c|}
\hline Participants & Statements \\
\hline $\mathrm{SH} / \mathrm{PDO}-\mathrm{CL}$ & $\begin{array}{l}\text { Shepherds children do not stay. I know of no case close by where children } \\
\text { have continued. The old people are dying or have no longer the capacity to go } \\
\text { on working. }\end{array}$ \\
\hline $\mathrm{SH} / \mathrm{CH}-\mathrm{AF}$ & $\begin{array}{l}\text { It doesn't matter whether you have children or not. As the elders go away } \\
\text { farms end. Everyone is giving up. There are easier jobs, a cleaner life, a more } \\
\text { peaceful life and nowadays everyone want that. }\end{array}$ \\
\hline & $\begin{array}{l}\text { the shepherd's sons and daughters have a cold and poor representation of } \\
\text { pastoralism... I do not think that they will return to became shepherds, } \\
\text { working from sunrise to sunset, earning the minimum wage, catching rain, } \\
\text { without having the right to date, to go on holidays, not having the right to }\end{array}$ \\
\hline $\mathrm{C}-\mathrm{H}$ & $\begin{array}{l}\text { drink a glass of wine by the sea, not having the right to what any human being } \\
\text { is entitled today: leisure and pleasure; ( ... ) they have the right to denial: "I } \\
\text { don't want my father's life, I don't want this representation; even if I could } \\
\text { earn a lot of money, I don't want to build my home in the place where I } \\
\text { suffered ... ". }\end{array}$ \\
\hline $\mathrm{M}-\mathrm{H}$ & Nowadays we want to hire a shepherd or a cheesemaker and there are none. \\
\hline $\mathrm{SH} / \mathrm{PDO}-\mathrm{CS}$ & $\begin{array}{l}\text { It is very difficult to find someone to work with the animals and the people } \\
\text { you find usually have no experience or doesn't want hard work. }\end{array}$ \\
\hline $\mathrm{SH} / \mathrm{PDO}-\mathrm{CL}$ & $\begin{array}{l}\text { I don't want my daughters in this kind of life. Not because of prestige but } \\
\text { because it is a hard life. }\end{array}$ \\
\hline PDO-PP & $\begin{array}{l}\text { I have } 4 \text { children: one is } 4 \text { years old and the others are } 18,19 \text { and } 23 \text {. The older } \\
\text { don't want this. They walk the other way. This is very hard, very hard, both in } \\
\text { the fields and cheese making... It is very hard ... }\end{array}$ \\
\hline $\mathrm{SH} / \mathrm{PDO}-\mathrm{CL}$ & $\begin{array}{l}\text { Most of them (shepherds) do not have descendants who want keep on the } \\
\text { farm. } 15 \text { years from now, our problem will be not having milk. The problem } \\
\text { won't be the price of cheese or the price of milk because there will be none. }\end{array}$ \\
\hline $\mathrm{T}-\mathrm{CH}$ & $\begin{array}{c}\text { The younger say that it is a job from Sunday to Sunday, they cannot have } \\
\text { holidays or even a single day for themselves. }\end{array}$ \\
\hline $\mathrm{T}-\mathrm{AC}$ & $\begin{array}{c}\text { They (shepherds) have no vacations. They do not have weekends because it is } \\
\text { a daily activity. They spend all day with the animals. Early in the morning } \\
\text { they have to milk, then they have to make the sheep beds, then take the herd to } \\
\text { the pastures and, finally, milk it again... }\end{array}$ \\
\hline $\mathrm{T}-\mathrm{CH}$ & $\begin{array}{l}\text { In this region a shepherd is still perceived as a foolish, drunk person, and it is } \\
\text { not easy to find someone available. Maybe what is paid is not attractive either. } \\
\text { But it is very difficult to get people to work in this area. }\end{array}$ \\
\hline M-JA & $\begin{array}{l}\text { The younger shepherds who remained increased their herds. But there are } \\
\text { fewer shepherds. Maybe more cheese is produced now, but smaller artisanal } \\
\text { cheesemakers have given up. }\end{array}$ \\
\hline $\mathrm{C}-\mathrm{H}$ & $\begin{array}{c}(\ldots) \text { whether or not there is people in the mountains makes a big difference } \\
\text { in fire control. }\end{array}$ \\
\hline $\mathrm{SH}-\mathrm{H}$ & The main firefighters are the animals and the population in the territory. \\
\hline
\end{tabular}

Table A5. Participants illustrative statements regarding the impact of Climate changes.

\begin{tabular}{c} 
Statements \\
\hline Participants \\
$\begin{array}{c}\text { The farrowing season is in September, and we start milking around October. In } \\
\text { the past, at vintage time, we used to sow ryegrass. Some rain had already } \\
\text { follow and the grass was starting to greening. Not now! Sometimes we don't } \\
\text { even have grass by the streams, because there is no water. Before, small } \\
\text { streams never dried. There is a wild difference. That's why, a few years ago, } \\
\text { milk production was better than now. All is due to the weather. Before, at } \\
\text { farrowing time we had pasture. Now, when animals need more food, we don't } \\
\text { have it. }\end{array}$ \\
$\begin{array}{c}\text { Shepherds have to face severe droughts, not to mention the fires. Droughts } \\
\text { messes up shepherds ... they have to give more commercial feeds to sheep } \\
\text { than usually ... }\end{array}$ \\
M-JA
\end{tabular}


Table A5. Cont.

\begin{tabular}{|c|c|}
\hline Participants & Statements \\
\hline SH/PDO-CS & $\begin{array}{l}\text { The weather is very uncertain. Last year, summer was very dry, very dry... We } \\
\text { have foggy and damp mornings every day. The climate is very different now. } \\
\text { I've always heard of rainy winters... last summer was really complicated. } \\
\text { Some producers did not have food for the sheep. As it did not rain, rye was } \\
\text { not born and they did not have food for the sheep. Some producers gave } \\
\text { potatoes and hay. }\end{array}$ \\
\hline $\mathrm{T}-\mathrm{CH}$ & $\begin{array}{l}\text { The climate doesn't help. Last year it was a year to forget. We had a huge cost } \\
\text { in feed. The summer was very hot, with little rain and then, in October, the big } \\
\text { fires came and burned a lot of pastures, a lot. It was chaos. This kind of things } \\
\text { lead shepherds to disappointment and to feelings like "I don't care about this } \\
\text { anymore; I'm going to migrate; I'm going to look for another job". }\end{array}$ \\
\hline T-RC & $\begin{array}{l}\text { In summer it is complicated because rainfed crops cannot grow with the } \\
\text { climate we are now experiencing: from June until October, there is zero rain ... }\end{array}$ \\
\hline $\mathrm{T}-\mathrm{CH}$ & $\begin{array}{l}\text { Traditionally sheep go out every day. Nowadays, however, they often come } \\
\text { out and have nothing to eat, no pasture, everything is dry ... }\end{array}$ \\
\hline SH-SA & $\begin{array}{l}\text { Each year is getting worse and animals suffer; the productions have nothing to } \\
\text { do with what it used to be... in the past when rain started it kept raining for } \\
\text { some time, the sheep were always at the same temperature. Not now, it heats } \\
\text { up, it cools down, and production slows down and never fully recovers. } \\
\text { In the past, in September, the first rains arrived and we started sowing. }\end{array}$ \\
\hline SH-VR & $\begin{array}{l}\text { Nowadays we do it in October and sometimes even later... In the last } 10-15 \\
\text { years there was a very sudden change in air. This year, for example, in summer } \\
\text { deliveries, lots of lambs died; it looked like there wasn't enough oxygen for } \\
\text { them to fill their lungs; many did not have the strength to suckle their mothers' } \\
\text { colostrum, they fell dad with } 2 / 3 \mathrm{~h} \text { of life. It is not that they were at the sun, } \\
\text { but the temperature was high and there was no fresh air like a few years ago } \\
\text { due to the grove. }\end{array}$ \\
\hline PDO-PP & $\begin{array}{l}\text { In my opinion what seems to have been interfering with cheese characteristics } \\
\text { is the climate, the change in the prevalence of cold and natural humidity ... }\end{array}$ \\
\hline
\end{tabular}

Table A6. Participants illustrative statements regarding the impact of globalization.

\begin{tabular}{|c|c|}
\hline Participants & Statements \\
\hline PDO-PP & Kids, even the children of shepherds and cheesemakers, eat "la Vache qui rit". \\
\hline $\mathrm{M}-\mathrm{H}$ & $\begin{array}{l}\text { We have to think like the consumers who bring us economic value. It is in the } \\
\text { large urban centers that cheese is consumed, not here. }\end{array}$ \\
\hline $\mathrm{C}-\mathrm{H}$ & $\begin{array}{c}\text { Big retailers are the ones who decide what we eat. They come here to pick up } \\
\text { our gourmet cheese for those who can afford it, while we eat the garbage } \\
\text { coming from the leftovers of the rich countries, because our salaries and } \\
\text { pensions are miserable. }\end{array}$ \\
\hline $\mathrm{C}-\mathrm{H}$ & $\begin{array}{l}\text { Serra da Estrela cheese is, in fact, more and more an export product, which is a } \\
\text { paradox: the people who produce it cannot afford it. }\end{array}$ \\
\hline $\mathrm{M}-\mathrm{H}$ & $\begin{array}{l}\text { Portugal has a minimum wage of about } 600 \text { euros. In France it is } 1500 \ldots \text { This } \\
\text { is a product for markets with high purchasing power, willing to pay for a } \\
\text { gastronomic experience. }\end{array}$ \\
\hline $\mathrm{M}-\mathrm{H}$ & $\begin{array}{c}\text { Today, people buy } 70 \% \text { communication and } 30 \% \text { product. The first thing } \\
\text { people buy is communication, packaging, storytelling...Serra da Estrela cheese } \\
\text { has a wonderful story to tell and is not made anywhere else in the country or } \\
\text { in the world. }\end{array}$ \\
\hline T-JM & $\begin{array}{c}\text { People were always here, they made cheese and someone came to buy it; today } \\
\text { it is not so. The name does have the notoriety, but you need to make things } \\
\text { right in the market, go further. }\end{array}$ \\
\hline $\mathrm{M}-\mathrm{H}$ & $\begin{array}{l}\text { We have DOP producers making an average of } 50-60 \text { cheeses per day; there is } \\
\text { no scale and it's impossible to reach modern distribution channels. }\end{array}$ \\
\hline $\mathrm{SH} / \mathrm{CH}-\mathrm{AA}$ & $\begin{array}{c}\text { Local markets are over; there are no more fairs. The middlemen who came to } \\
\text { the producers and bought not only the excellent quality cheese, but also the } \\
\text { other not so good, ended. This is over because people started to buy in } \\
\text { medium and large distribution channels. }\end{array}$ \\
\hline
\end{tabular}


Table A7. Participants illustrative statements regarding the impact of the end of public extension rural services.

\begin{tabular}{cc}
\hline Participants & Statements \\
T-RC & $\begin{array}{c}\text { In the past, the public services had rural extension brigades. Where are they } \\
\text { now? They were reassigned to producer's associations, but how many have } \\
\text { resisted? Doing what? Mainly filling applications to direct payments ... } \\
\text { ANCOSE (producer's association) in many ways replaced the public services. } \\
\text { Before we went to Tojal Mau (experimental center of the Ministry of } \\
\text { Agriculture) and brought an idea how to solve a problem (...) Today, that is } \\
\text { impossible. There were many more technicians in the field ... today I call }\end{array}$ \\
SH-VR & $\begin{array}{r}\text { Adubos de Portugal (agricultural inputs private company) and they come here } \\
\text { to sell their products. }\end{array}$ \\
SH/CH-AS & $\begin{array}{r}\text { Technical support is very difficult to get ... } \\
\text { SH/PDO-CS }\end{array}$ \\
Th-RC & $\begin{array}{r}\text { Technical advice is different from region to region. In Serra da Estrela just forget } \\
\text { it... Only ANCOSE does something ... }\end{array}$ \\
\hline
\end{tabular}

Table A8. Participants statements regarding the adoption of technic innovations.

\begin{tabular}{|c|c|}
\hline Participants & Statements \\
\hline $\mathrm{T}-\mathrm{CH}$ & $\begin{array}{l}\text { Sheep breed is the most serious problem in Serra da Estrela cheese production. } \\
\text { Some years ago it was fashionable to move to Lacaune. }\end{array}$ \\
\hline $\mathrm{SH}-\mathrm{H}$ & $\begin{array}{l}\text { Nowadays there are many more Lacaune than Bordaleira sheep. Lacaune sheep } \\
\text { give as much milk as cows ... but shepherds don't think on how much } \\
\text { they eat. }\end{array}$ \\
\hline PDO-PP & $\begin{array}{l}\text { The number of Lacaune ewes has increased; it's a more productive breed and } \\
\text { when milk is to be sold by the liter, then it is worthy; the price is not that lower, } \\
\text { sometimes there is no difference. }\end{array}$ \\
\hline $\mathrm{T}-\mathrm{CH}$ & $\begin{array}{l}\text { Until } 3 \text { years ago the industries payed the same for Bordaleira sheep milk and } \\
\text { other milk; the price was the same and Lacaune gives much more milk } \\
\text { than Bordaleira. }\end{array}$ \\
\hline $\mathrm{SH} / \mathrm{CH}-\mathrm{AA}$ & We replaced all our Bordaleira by Lacaune; we now get three times more milk. \\
\hline $\mathrm{T}-\mathrm{AC}$ & There are practically no sheep in the mountain nowadays. \\
\hline T-JM & $\begin{array}{l}\text { Winter transhumance ended at the beginning of the 20th century and summer } \\
\text { transhumance ended at the end of the 20th century. Today very few herds go } \\
\text { to the top of the mountain to eat Nardum stricta. }\end{array}$ \\
\hline $\mathrm{C}-\mathrm{H}$ & $\begin{array}{l}\text { Shepherds no longer climb the mountains, they stay in the plains; as the plains } \\
\text { around the villages became abandoned, shepherds find pasture close to home } \\
\text { and do not need to go to the mountain; this have changed the vegetation and } \\
\text { the landscape. }\end{array}$ \\
\hline $\mathrm{SH}-\mathrm{H}$ & $\begin{array}{l}\text { What the cattle eat in the mountains or in the sown pastures is not the same } \\
\text { and this can make a difference, I think. }\end{array}$ \\
\hline $\mathrm{SH} / \mathrm{PDO}-\mathrm{CS}$ & $\begin{array}{c}\text { We have irrigation and managed to have green pasture, even in October } \\
\text { and November }\end{array}$ \\
\hline $\mathrm{T}-\mathrm{RC}$ & It's a vicious cycle: people have no money and irrigation is expensive. \\
\hline T-JM & $\begin{array}{l}\text { The mainly innovations were small changes that freed people from repetitive } \\
\text { tasks: cheese makers use a shaker instead of a spoon, small pneumatic } \\
\text { squeezers instead of their hands, ... In the past, some shepherds did not filter } \\
\text { the milk and now everybody has stainless steel utensils and disposable filters. } \\
\text { Now, cheesemakers have ripening chambers with air-conditioned to try to } \\
\text { reproduce the ideal conditions for cheese evolution. }\end{array}$ \\
\hline M-JA & $\begin{array}{l}\text { Now we have a much more regular flavor because we have a precision scale, } \\
\text { to weigh the thistle and control its influence on the flavor. }\end{array}$ \\
\hline T-PM & $\begin{array}{l}\text { Refrigeration of cheese, and milk, allowed the production of cheese } \\
\text { throughout the year. It stabilizes the quality of the cheese because the cold is } \\
\text { uniform. More cheese is produced, with higher average quality, more uniform. }\end{array}$ \\
\hline
\end{tabular}


Table A8. Cont.

\begin{tabular}{cc}
\hline Participants & \multicolumn{1}{c}{ Statements } \\
\hline & $\begin{array}{l}\text { My grandmother managed to have buttery or semi-buttery cheese in January, } \\
\text { FH/CH-AA }\end{array}$ \\
& $\begin{array}{r}\text { February and March. After that, hot weather started and she could only make } \\
\text { hard cheese. Now, with the ripening chambers, we have more control and we } \\
\text { can produce a buttery cheese until the end of June. }\end{array}$ \\
\hline
\end{tabular}

Table A9. Participants statements regarding the adoption of social innovations.

\begin{tabular}{|c|c|}
\hline Participants & Statements \\
\hline M-JA & $\begin{array}{l}\text { At the highest point we possessed around } 250 \text { sheep; we still have all the } \\
\text { structure but we gave it to a shepherd who supplies milk to us; currently we } \\
\text { are only focused on cheese production. }\end{array}$ \\
\hline M-JA & $\begin{array}{l}\text { The owner of the shop does not live here; she comes here from time to time to } \\
\text { spend the holidays but doesn't live here. }\end{array}$ \\
\hline $\mathrm{T}-\mathrm{CH}$ & $\begin{array}{l}\text { I have been working here for } 17 \text { years and, at that time, there was no tradition } \\
\text { of buying milk. Everyone had their herd, made the cheese from their herd and } \\
\text { sell it directly. Then everything started to change ... }\end{array}$ \\
\hline $\mathrm{T}-\mathrm{CH}$ & $\begin{array}{l}\text { The tradition of the husband being the shepherd and the wife the cheesemaker } \\
\text { is a thing of the past. The remaining producers increased production and } \\
\text { started buying milk and hiring employees. These new larger cheese factories } \\
\text { have many employees. }\end{array}$ \\
\hline $\mathrm{SH} / \mathrm{CH}-\mathrm{AF}$ & $\begin{array}{l}\text { Here everyone works in every tasks, as needed. There is no divided work, } \\
\text { each one doing his own tasks. In the past I didn't make cheese, it was a } \\
\text { women's job. The shepherd took care of the flock, did the milking and took the } \\
\text { milk home. The rest was the lady job, she was the one who made the cheese. }\end{array}$ \\
\hline $\mathrm{SH} / \mathrm{CH}-\mathrm{AR}$ & $\begin{array}{l}\text { Having sheep and processing it's a mess, you don't have time for anything. } \\
\text { Nowadays, this profession is more demanding. The producer must have }\end{array}$ \\
\hline $\mathrm{SH} / \mathrm{CH}-\mathrm{AF}$ & $\begin{array}{l}\text { knowledge of several things. One needs to know how to use the internet, how } \\
\text { to use a computer... The shepherd has to be a different shepherd; other } \\
\text { knowledge is needed, not only about sheep. In the old days, the shepherd was } \\
\text { a shepherd and did nothing else. Shepherds didn't have to go to the tax office } \\
\text { or the city council, they didn't have to communicate. }\end{array}$ \\
\hline $\mathrm{SH} / \mathrm{PDO}-\mathrm{CS}$ & $\begin{array}{l}\text { The cheese still manually processed, but in a different way because the amount } \\
\text { of milk is much higher. }\end{array}$ \\
\hline T-RC & $\begin{array}{l}\text { In my opinion, a few years ago one could find exceptional cheeses but not now. } \\
\text { The average quality is higher but excellence is rarer. }\end{array}$ \\
\hline $\mathrm{SH} / \mathrm{PDO}-\mathrm{CS}$ & $\begin{array}{c}\text { They (the new Serra da Estrela cheese factories) are able to influence people that } \\
\text { are not available for small producers and bring skills in management and } \\
\text { marketing. }\end{array}$ \\
\hline $\mathrm{T}-\mathrm{CH}$ & $\begin{array}{l}\text { They (the new Serra da Estrela cheese factories) produce cheese like a small } \\
\text { cheese shop. With bigger utensils, but it's all manual ... Everything remains } \\
\text { the same. We weren't used to so many brochures, so much advertising. They } \\
\text { are betting on exports and have invested a lot in advertising. }\end{array}$ \\
\hline $\mathrm{SH} / \mathrm{CH}-\mathrm{AF}$ & $\begin{array}{c}\text { They have the financial ability ... They are rich people who want, can and } \\
\text { know. They think they can do it, but they haven't the key factor: they don't get } \\
\text { quality. }\end{array}$ \\
\hline $\mathrm{SH} / \mathrm{CH}-\mathrm{AR}$ & $\begin{array}{c}\text { I am not against this new factories, because if it weren't for the factories, } 90 \% \\
\text { of the shepherds, or more, would be over in a year! }\end{array}$ \\
\hline $\mathrm{T}-\mathrm{AC}$ & $\begin{array}{l}\text { Some time ago I went to a cheese factory opening and I didn't like that cheese. } \\
\text { The people who makes the cheese have never made cheese in their lives before, } \\
\text { they were hired. Quality and specificity have been lost. }\end{array}$ \\
\hline
\end{tabular}


Table A10. Participants illustrative statements regarding innovations at the marketing level.

\begin{tabular}{|c|c|}
\hline Participants & Statements \\
\hline SH/PDO-CL & $\begin{array}{l}\text { Before, we could not produce PDO cheese weighing less than } 1 \mathrm{~kg} \text {. Then it } \\
\text { dropped to } 700 \text { or } 800 \mathrm{~g} \text { and now we can get down to } 0.5 \mathrm{~kg} \text {. That's because } \\
\text { the market is asking for smaller cheeses. Large markets usually ask for smaller } \\
\text { units because they are cheaper. It has to do with purchasing power. }\end{array}$ \\
\hline SH/PDO-CS & $\begin{array}{l}\text { Nowadays some customers, especially those who resell the cheese in the big } \\
\text { cities, only want half a kilo cheese. }\end{array}$ \\
\hline T-AC & $\begin{array}{l}\text { Cheese has never been this small, because cheeses were made for the } \\
\text { shepherds to take and eat when they stayed for a long time in the mountains. } \\
\text { ( . . . ) some new producers are starting to increase in size, in scale, gaining }\end{array}$ \\
\hline $\mathrm{M}-\mathrm{H}$ & $\begin{array}{c}\text { strength and creating a dynamic of value increasing, differentiating Serra da } \\
\text { Estrela cheese from the industrial cheese }(\ldots) \text {. In order to sell more and grow } \\
\text { international markets are vital. }\end{array}$ \\
\hline SH/PDO-CS & $\begin{array}{l}\text { This October we started to sell cheese to a shop in Lisbon that makes cod cakes } \\
\text { with Serra da Estrela cheese. }\end{array}$ \\
\hline $\mathrm{T}-\mathrm{CH}$ & $\begin{array}{c}\text { The cod cakes company helped a lot, particularly small producers. Larger } \\
\text { producers sell to big retailers... }\end{array}$ \\
\hline PDO-PP & $\begin{array}{l}\text { The casein label has become mandatory. A differentiating element in the } \\
\text { cheese, apart from the label, that could identify the cheesemaker, was needed. }\end{array}$ \\
\hline
\end{tabular}

Table A11. Participants statements regarding the system governance.

\begin{tabular}{|c|c|}
\hline Participants & Statements \\
\hline $\mathrm{SH} / \mathrm{PDO}-\mathrm{CL}$ & $\begin{array}{l}\text { Today the Ministry of Agriculture is there to inspect us. They do anything else. } \\
\text { I don't know how many technicians are in the ministry, but none or almost } \\
\text { none are in the field. }\end{array}$ \\
\hline T-JM & $\begin{array}{l}\text { I even think that people live a little terrified by the imminence of a visit, an } \\
\text { inspection; people do not understand why things have to be done in a certain } \\
\text { way, it is not explained to them. }\end{array}$ \\
\hline T-AC & $\begin{array}{l}\text { In the eighties Serra da Estrela cheese production area was delimited and } \\
\text { municipal associations had to be created to give rise to a Federation. We had to } \\
\text { persuade the producers to attend the plenary sessions to elect the governing } \\
\text { bodies. They were not interested. Nowadays these associations no longer exist. }\end{array}$ \\
\hline PDO-PP & $\begin{array}{l}\text { Estrelacoop is a producer's organization but the word cooperative is a little } \\
\text { misleading... It is not a cooperative where people come together and create } \\
\text { synergies to solve common problems. This kind of thing does not exist here. }\end{array}$ \\
\hline $\mathrm{T}-\mathrm{CH}$ & $\begin{array}{l}\text { Always the same people go (to Estrelacoop General Meetings). It's funny that } \\
\text { they are always the same. But it's not that they are very participative. They } \\
\text { like to know what's going on, but they don't ask questions. As soon as they } \\
\text { sell the cheese, they feel happy. }\end{array}$ \\
\hline $\mathrm{SH} / \mathrm{CH}-\mathrm{AS}$ & $\begin{array}{l}\text { I can only say good things about ANCOSE; any problem I have, they come and } \\
\text { try to help... but they could work a little better... Some people criticize } \\
\text { ANCOSE a lot, but not me. But they could do a little more... }\end{array}$ \\
\hline T-JM & $\begin{array}{c}\text { In order to ask for something people must participate, go to general meetings. } \\
\text { They can't just say bad things in the pub and do nothing. But some of the } \\
\text { shepherds recognize ANCOSE work and know that things would not be the } \\
\text { same if ANCOSE did not exist. }\end{array}$ \\
\hline $\mathrm{SH} / \mathrm{CH}-\mathrm{AF}$ & $\begin{array}{l}\text { I was a member of everything but today I am a member of nothing. I gave up } \\
\text { everything. The years have been teaching me ... I quit certification a few } \\
\text { years ago. I was never a person that speaks a lot in meetings. I'd rather listen } \\
\text { to better understand the paths, what is happening, how things work, and then } \\
\text { draw my own conclusions. I wasn't there to argue; I was never one of those } \\
\text { people. Later, I left because I saw that it could not stand on its own two feet, in } \\
\text { terms of helping producers, in terms of helping those who work... Whoever } \\
\text { runs these associations are outsiders that have nothing to do with the } \\
\text { producers. A shepherd has no active voice, he is always seen as an illiterate... }\end{array}$ \\
\hline
\end{tabular}


Table A11. Cont.

\begin{tabular}{|c|c|}
\hline Participants & Statements \\
\hline & $\begin{array}{l}\text { I do not participate (in the activities of producer organizations), because I am } \\
\text { very busy and I think that those who do not have time should not be there. I }\end{array}$ \\
\hline SH/DOP-CL & $\begin{array}{l}\text { have already been invited, but I have no time. When I accept to join a project, I } \\
\text { have to know what is going on there because if I join just to say "Amen" and } \\
\text { not even know what is going on, what am I doing there? }\end{array}$ \\
\hline $\mathrm{SH} / \mathrm{DOP}-\mathrm{CL}$ & $\begin{array}{l}\text { If I talk to any producer, he will say that that the association board cannot stay, } \\
\text { that this guy and that guy do nothing ... it is always the same talk. But, when } \\
\text { D-day arrives, no one steps forward, nobody wants to go. I can't explain it! }\end{array}$ \\
\hline SH-VR & We (shepherds) don't have an organizational structure. Sometimes, casually, \\
\hline SH-SA & some of us get together and talk about our problems. \\
\hline $\mathrm{SH} / \mathrm{CH}-\mathrm{AR}$ & $\begin{array}{l}\text { It is often said that secrecy is the soul of business. If we open up to someone, } \\
\text { we are done. I've helped a lot of people, and behind my back they were setting } \\
\text { me up. No, you do your life, I do mine... It's the best thing to do... }\end{array}$ \\
\hline
\end{tabular}

\section{References}

1. Oteros-rozas, E.; González, J.A.; Martín-lópez, B.; López, C.A.; Zorrilla-miras, P.; Montes, C. Evaluating Ecosystem Services in Transhumance Cultural Landscapes: An Interdisciplinary and Participatory Framework. GAIA 2012, 21, 185-193. [CrossRef]

2. Dean, G.; Rivera-ferre, M.G.; Rosas-casals, M.; Lopez-i-gelats, F. Nature's contribution to people as a framework for examining socioecological systems: The case of pastoral systems. Ecosyst. Serv. 2021, 49, 101265. [CrossRef]

3. Pardini, A.; Nori, M. Agro-silvo-pastoral systems in Italy: Integration and diversification. Pastoralism 2011, 1, 26. [CrossRef]

4. Caballero, R.; Fernandez-Gonzalez, F.; Badia, R.P.; Molle, G.; Roggero, P.P.; Bagella, S.; Papanastasis, V.P.; Fotiadis, G.; Sidiropoulou, A.; Ispikoudis, I. Grazing systems and biodiversity in Mediterranean areas: Spain, Italy and Greece. Pastos 2009, 39, 9-152.

5. Berriet-Solliec, M.; Lataste, F.; Lépicier, D.; Piguet, V. Environmentally and socially beneficial outcomes produced by agro-pastoral systems in the Cévennes National Park (France). Land Use Policy 2018, 78, 739-747. [CrossRef]

6. Ripoll-Bosch, R.; Díez-Unquera, B.; Ruiz, R.; Villalba, D.; Molina, E.; Joy, M.; Olaizola, A.; Bernués, A. An integrated sustainability assessment of mediterranean sheep farms with different degrees of intensification. Agric. Syst. 2012, 105, 46-56. [CrossRef]

7. Farris, E.; Filigheddu, R.; Deiana, P.; Farris, G.A.; Garau, G. Short-term effects on sheep pastureland due to grazing abandonment in a Western Mediterranean island ecosystem: A multidisciplinary approach. J. Nat. Conserv. 2010, 18, 258-267. [CrossRef]

8. Bagella, S.; Caria, M.C.; Farris, E.; Rossetti, I.; Filigheddu, R. Traditional land uses enhanced plant biodiversity in a Mediterranean agro-silvo-pastoral system. Plant Biosyst. Int. J. Deal. Asp. Plant Biol. 2016, 150, 201-207. [CrossRef]

9. Statistics Portugal. Agriculture Census-Historical Series. Available online: http:/ / www.ine.pt (accessed on 15 March 2021).

10. Walker, B.; Holling, C.S.; Carpenter, S.R.; Kinzig, A. Resilience, adaptability and transformability in social-ecological systems. Ecol. Soc. 2004, 9, 5. [CrossRef]

11. Nettier, B.; Dobremez, L.; Lavorel, S.; Brunschwig, G. Resilience as a framework for analyzing the adaptation of mountain summer pasture systems to climate change. Ecol. Soc. 2017, 22, 25. [CrossRef]

12. $\mathrm{Wu}, \mathrm{Z}$; $\mathrm{Li}, \mathrm{B}$; $\mathrm{Hou}, \mathrm{Y}$. Adaptive choice of livelihood patterns in rural households in a farm-pastoral zone: A case study in Jungar, Inner Mongolia. Land Use Policy 2017, 62, 361-375. [CrossRef]

13. Stayner, R. The changing economics of rural communities. In Sustainability and Change in Rural Australia; Coklin, C., Dibdin, J., Eds.; University of New South Wales Press: Sydney, Australia, 2005; pp. 121-138.

14. Schouten, M.; van der Heide, C.; Heijman, W.; Opdam, P. A resilience-based policy evaluation framework: Application to European rural development policies. Ecol. Econ. 2012, 81, 165-175. [CrossRef]

15. Bardsley, D.K.; Bardsley, A.M. Organising for socio-ecological resilience: The roles of the mountain farmer cooperative genossenschaft gran alpin in graubünden, switzerland. Ecol. Econ. 2014, 98, 11-21. [CrossRef]

16. Altieri, M.A.; Nicholls, C.I.; Henao, A.; Lana, M.A. Agroecology and the design of climate change-resilient farming systems. Agron. Sustain. Dev. 2015, 35, 869-890. [CrossRef]

17. Lin, B.B. Resilience in Agriculture trough Crop Diversification: Adaptive Management for Environmental Change. Bioscience 2011, 61, 183-193. [CrossRef]

18. Sanz, M.J.; De Vente, J.; Chotte, J.L.; Bernoux, M.; Kust, G.S.; Ruiz, I.; Almagro, M.; Alloza, J.A.; Vallejo, R.; Castillo, V.; et al. Sustainable Land Management Contribution to Successful Land-Based Climate Change Adaptation and Mitigation. A Report of the Science-Policy Interface; United Nations Convention to Combat Desertification (UNCCD): Bonn, Germany, 2017.

19. Holling, C.S. Resilience and Stability of Ecological Systems. Annu. Rev. Ecol. Syst. 1973, 4, 1-23. [CrossRef]

20. Pal, R.; Torstensson, H.; Mattila, H. Antecedents of Organizational Resilience in Economic Crises-An Empirical Study of Swedish Textile and Clothing SMEs. Int. J. Prod. Econ. 2014, 147, 410-428. [CrossRef]

21. de Sanctis, I.; Meré, J.O.; Ciarapica, F.E. Resilience for lean organisational network. Int. J. Prod. Res. 2018, 56, 6917-6936. [CrossRef] 
22. Kovács, G.; Matopoulos, A.; Hayes, O. A community-based approach to supply chain design. Int. J. Logist. Res. Appl. 2010, 13, 411-422. [CrossRef]

23. Guo, J.; Zhu, X.; Liu, C.; Ge, S. Resilience Modeling Method of Airport Network Affected by Global Public Health Events. Math. Probl. Eng. 2021, 2021, 6622031. [CrossRef]

24. Padel, S.; Lampkin, N.; Foster, C. Influence of policy support on the development of organic farming in the European Union. Int. Plan. Stud. 1999, 4, 303-315. [CrossRef]

25. Cariolet, J.M.; Colombert, M.; Vuillet, M.; Diab, Y. Assessing the resilience of urban areas to traffic-related air pollution: Application in Greater Paris. Sci. Total Environ. 2018, 615, 588-596. [CrossRef]

26. Bolaños-Guerra, B.; Calderón-Contreras, R. Desafíos de resiliencia para disminuir la migración inducida por causas ambientales desde Centroamérica. Rev. Estud. Soc. 2021, 7-23. [CrossRef]

27. Heijman, W.; Hagelaar, G.; Heide, M. Rural resilience as a new development concept. In Proceedings of the EAAE 100 Seminar, Novi Sad, Serbia, 21-23 June 2007; pp. 383-396.

28. Walker, B.; Salt, D. Resilience Thinking: Sustaining Ecosystems and People in a Changing World; Island Press: Washington, DC, USA, 2006.

29. Schouten, M.; van der Heide, M.; Heijaman, W. Resilience of social-ecological systems in european rural areas: Theory and prospects. In Proceedings of the EAAE 113 Seminar, Belgrade, Serbia, 9-11 December 2009; pp. 1-18.

30. Gunderson, L.; Kinzig, A.; Quinlan, A.; Walker, B. Assessing Resilience in Social-Ecological Systems: Workbook for Practitioners, 2nd ed.; Resilience Alliance: Wolfville, NS, Canada, 2010.

31. Colding, J.; Barthel, S. Exploring the social-ecological systems discourse 20 years later. Ecol. Soc. 2019, 24, 2. [CrossRef]

32. Folke, C.; Carpenter, S.R.; Walker, B.; Scheffer, M.; Chapin, T.; Rockström, J. Resilience Thinking: Integrating Resilience, Adaptability and Transformability. Ecol. Soc. 2010, 15, 20. [CrossRef]

33. Dorresteijn, I.; Loos, J.; Hanspach, J.; Fischer, J. Socioecological drivers facilitating biodiversity conservation in traditional farming landscapes. Ecosyst. Heal. Sustain. 2015, 1, 1-9. [CrossRef]

34. Cabell, J.F.; Oelofse, M. An indicator framework for assessing agroecosystem resilience. Ecol. Soc. 2012, 17, 18. [CrossRef]

35. Stokols, D.; Lejano, R.P.; Hipp, J. Enhancing the Resilience of Human-Environment Systems: A Social perspective. Ecol. Soc. 2013, 18, 7. [CrossRef]

36. Holling, C.S. Understanding the complexity of economic, ecological, and social systems. Ecosystems 2001, 4, 390-405. [CrossRef]

37. Gunderson, L.H.; Holling, S. Panarchy: Understanding Transformations in Human and Natural Systems; Island Pre.: Washington, DC, USA, 2002.

38. Darnhofer, I.; Lamine, C.; Strauss, A.; Navarrete, M. The resilience of family farms: Towards a relational approach. J. Rural Stud. 2016, 44, 111-122. [CrossRef]

39. O'Connell, D.; Abel, N.; Grigg, N.; Maru, Y.; Butler, J.; Cowie, A.; Stone-Jovicich, S.; Walker, B.; Wise, R.; Ruhweza, A.; et al. Designing Projects in a Rapidly Changing World: Guidelines for Embedding Resilience, Adaptation and Transformation into Sustainable Development Projects, 1st ed.; Global Env.: Washington, DC, USA, 2016.

40. Cumming, G.S.; Peterson, G.D. Unifying Research on Social-Ecological Resilience and Collapse. Trends Ecol. Evol. 2017, 32, 695-713. [CrossRef]

41. Carpenter, S.; Walker, B.; Anderies, J.M.; Abel, N. From Metaphor to Measurement: Resilience of What to What? Ecosystems 2001, 4, 765-781. [CrossRef]

42. Brunner, S.H.; Grêt-Regamey, A. Policy strategies to foster the resilience of mountain social-ecological systems under uncertain global change. Environ. Sci. Policy 2016, 66, 129-139. [CrossRef]

43. Downey, S. Can properties of labor-exchange networks explain the resilience of swidden agriculture. Ecol. Soc. 2010, 15, 15. [CrossRef]

44. Ruiz-Ballesteros, E. Social-ecological resilience and community-based tourism. Tour. Manag. 2011, 32, 655-666. [CrossRef]

45. Sutherland, L.-A.; Burton, R.J.F.; Ingram, J.; Blackstock, K.; Slee, B.; Gotts, N. Triggering change: Towards a conceptualisation of major change processes in farm decision-making. J. Environ. Manag. 2012, 104, 142-151. [CrossRef] [PubMed]

46. Tenza, A.; Pérez, I.; Martínez-Fernández, J.; Giménez, A. Understanding the decline and resilience loss of a long-lived socialecological system: Insights from system dynamics. Ecol. Soc. 2017, 22, 15. [CrossRef]

47. Spies, M. Changing food systems and their resilience in the Karakoram Mountains of Northern Pakistan: A case study of nagar. Mt. Res. Dev. 2018, 38, 299-309. [CrossRef]

48. Rescia, A.J.; Willaarts, B.A.; Schmitz, M.F.; Aguilera, P.A. Changes in land uses and management in two Nature Reserves in Spain: Evaluating the social-ecological resilience of cultural landscapes. Landsc. Urban Plan. 2010, 98, 26-35. [CrossRef]

49. Tomczyk, A.M.; White, P.C.L.; Ewertowski, M.W. Effects of extreme natural events on the provision of ecosystem services in a mountain environment: The importance of trail design in delivering system resilience and ecosystem service co-benefits. J. Environ. Manag. 2016, 166, 156-167. [CrossRef]

50. Berrouet, L.M.; Machado, J.; Villegas-Palacio, C. Vulnerability of socio-ecological systems: A conceptual Framework. Ecol. Indic. 2018, 84, 632-647. [CrossRef]

51. Luthe, T.; Wyss, R.; Schuckert, M. Network governance and regional resilience to climate change: Empirical evidence from mountain tourism communities in the Swiss Gotthard region. Reg. Environ. Chang. 2012, 12, 839-854. [CrossRef]

52. Schermer, M.; Darnhofer, I.; Daugstad, K.; Gabillet, M.; Lavorel, S.; Steinbacher, M. Institutional impacts on the resilience of mountain grasslands: An analysis based on three European case studies. Land Use Policy 2016, 52, 382-391. [CrossRef] 
53. Gotts, N.M.; van Voorn, G.A.; Polhill, J.G.; de Jong, E.; Edmonds, B.; Hofstede, G.J.; Meyer, R. Agent-based modelling of socio-ecological systems: Models, projects and ontologies. Ecol. Complex. 2019, 40, 100728. [CrossRef]

54. Bakker, K. The limits of 'neoliberal natures': Debating green neoliberalism. Prog. Hum. Geogr. 2010, 34, 715-735. [CrossRef]

55. Midmore, P.; Whittaker, J. Economics for sustainable rural systems. Ecol. Econ. 2000, 35, 173-189. [CrossRef]

56. Darnhofer, I.; Bellon, S.; Dedieu, B.; Milestad, R. Adaptiveness to enhance the sustainability of farming systems: A review. Agron. Sustain. 2010, 30, 545-555. [CrossRef]

57. Walker, B.; Salt, D. Resilience Practice: Building Capacity to Absorb Disturbance and Maintain Function; Island Press: Washington, DC, USA, 2012.

58. Šūmane, S.; Kunda, I.; Knickel, K.; Strauss, A.; Tisenkopfs, T.; des Ios Rios, I.; Rivera, M.; Chebach, T.; Ashkenazy, A. Local and farmers' knowledge matters! How integrating informal and formal knowledge enhances sustainable and resilient agriculture. J. Rural Stud. 2018, 59, 232-241. [CrossRef]

59. Berkes, F. Understanding uncertainty and reducing vulnerability: Lessons from resilience thinking. Nat. Hazards 2007, 41, 283-295. [CrossRef]

60. Ostrom, E.; Cox, M. Moving beyond panaceas: A multi-tiered diagnostic approach for social-ecological analysis. Environ. Conserv. 2010, 37, 451-463. [CrossRef]

61. Parsonson-Ensor, C.; Saunders, C.M. Exploratory Research into the Resilience of Farming Systems during Periods of Hardship. In Proceedings of the 2011 New Zealand Agricultural and Resource Economics Society Conference, Nelson, New Zealand, 25-26 August 2011.

62. Callaghan, E.G.; Colton, J. Building sustainable \& resilient communities: A balancing of community capital. Environ. Dev. Sustain. 2009, 10, 931-942.

63. Folke, C.; Carpenter, S.; Elmqvist, T.; Gunderson, L.; Holling, C.; Walker, B. Resilience and Sustainable Development: Building Adaptive Capacity in a World of Transformations. Ambio 2002, 31, 437-440. [CrossRef] [PubMed]

64. Walker, B.; Carpenter, S.; Anderies, J.; Abel, N.; Cumming, G.; Janssen, M.; Lebel, L.; Norberg, J.; Peterson, G.D.; Pritchard, R. Resilience management in social-ecological systems: A working hypothesis for a participatory approach. Ecol. Soc. 2002, 6, 14. [CrossRef]

65. Given, L. 100 Questions (and Answers) About Qualitative Research; SAGE Publications: Thousand Oaks, CA, USA, 2016.

66. Saunders, B.; Sim, J.; Kingstone, T.; Baker, S.; Waterfield, J.; Bartlam, B.; Burroughs, H.; Jinks, C. Saturation in qualitative research: Exploring its conceptualization and operationalization. Qual. Quant. 2018, 52, 1893-1907. [CrossRef] [PubMed]

67. Drisko, J.; Maschi, T. Content Analysis; Oxford Uni.: Oxford, UK, 2015.

68. DGADR. Produtos Tradicionais Portugueses: Produtos Agrícolas, Géneros Alimentícios e Pratos Preparados. Available online: https:/ / tradicional.dgadr.gov.pt/pt/cat/queijos-e-produtos-lacteos/31-queijo-da-serra-da-estrela (accessed on 17 March 2020).

69. Statistics Portugal. Annual Estimates of Resident Population. Available online: http:/ / www.ine.pt (accessed on 15 March 2021).

70. Statistics Portugal. Population and Housing Census 2011. Available online: http:/ / www.ine.pt (accessed on 15 March 2021).

71. Statistics Portugal. Integrated Business Accounts System. Available online: http:/ / www.ine.pt (accessed on 15 March 2021).

72. Fanelli, R.M. A new classification of European union regions: A decision support tool for policymakers. Spanish J. Agric. Res. 2019, 17, 1-16. [CrossRef]

73. Madureira, L.; Magalhães, P.; Silva, P.G.; Marinho, C.; Oliveira, R. Economia dos Serviços de Ecossistema-Um guia para Conhecer e Valorizar Serviços de Agroecossistemas em áreas Protegidas de Montanha; Quercus: Lisboa, Portugal, 2013.

74. Rosa, N. Manteigas no Outro lado do Tempo: Décadas de 1950 e 1960; Chiado Books: Lisbon, Portugal, 2017.

75. Jansen, J.; Castro, P.; Costa, L. Economic-ecological interactions in the Serra da Estrela, Portugal. In Economy and Ecology of Heathlands: Heathland Ecology and Management; Diemond, W., Heijman, W., Siepel, H., Webb, N., Eds.; KNNV Publishing: Zeist, The Netherlands, 2013; pp. 65-89.

76. State of Victoria. Goulburn Broken Regional Catchment Strategy. Shepparton. 2013. Available online: https://www.gbcma.vic. gov.au/downloads/RegionalCatchmentStrategy/GBCMA_RCS_2013-19.pdf (accessed on 2 February 2019).

77. Fogeiro, É.; Barracosa, P.; Oliveira, J.; Wessel, D.F. Influence of Cardoon (Cynara cardunculus L.) and Flock Lactation Stage in PDO Serra da Estrela cheese. Foods 2020, 9, 386. [CrossRef]

78. Flury, C.; Huber, R.; Tasser, E. Future of mountain agriculture in the Alps. In The Future of Mountain Agriculture; Mann, S., Ed.; Springer: Berlin/Heidelberg, Germany, 2013; pp. 105-126.

79. Arfini, F.; Antonioli, F.; Cozzi, E.; Donati, M.; Guareschi, M.; Mancini, M.C.; Veneziani, M. Sustainability, innovation and rural development: The case of Parmigiano-Reggiano PDO. Sustainability 2019, 11, 4978. [CrossRef]

80. Barnes, R. The Capacity of Property Rights to Accommodate Social-Ecological Resilience. Ecol. Soc. 2013, 18, 6. [CrossRef]

81. Martino, J.; Freitas, S. Consumo de queijos com DOP. Centro de Portugal. Ruris/Queijos Centro Portugal (unpublished manuscript). 2021.

82. Marie, C.D.S.; Mariani, M.; Millet, M. Can raw milk cheese and pasteurised milk cheese coexist? Unthinkable or never really considered? Rev. Agric. Food Environ. Stud. 2020, 101, 287-309. [CrossRef]

83. Gunasekaran, A.; Rai, B.K.; Griffin, M. Resilience and competitiveness of small and medium size enterprises: An empirical research. Int. J. Prod. Res. 2011, 49, 5489-5509. [CrossRef]

84. Fanelli, R.M. The spatial and temporal variability of the effects of agricultural practices on the environment. Environments 2020, 7 , 33. [CrossRef] 
85. Janssen, M.A.; Bodin, Ö.; Anderies, J.M.; Elmqvist, T.; Ernstson, H.; McAllister, R.R.; Olsson, P.; Ryan, P. Toward a Network Perspective of the Study of Resilience in Social-Ecological Systems. Ecol. Soc. 2006, 11, 15. [CrossRef]

86. Crane, T. Of models and meanings: Cultural resilience in social-ecological systems. Ecol. Soc. 2010, 15, 19. [CrossRef]

87. Martino, J.; Lopes, A. Modelo técnico-económico para a produção de leite e para o fabrico de Queijo Serra da Estrela DOP Programa da Valorização da Fileira do Queijo da Região Centro de Portugal. Ruris/Queijos Centro Portugal (unpublished manuscript). 2021.

88. Abel, N.; Cumming, D.H.M.; Anderies, J.M. Collapse and reorganization in social-ecological systems: Question, some ideas, and policy implications. Ecol. Soc. 2006, 11, 17. [CrossRef]

89. Cote, M.; Nightingale, A.J. Resilience thinking meets social theory: Situating social change in socio-ecological systems (SES) research. Prog. Hum. Geogr. 2012, 36, 475-489. [CrossRef] 